\title{
Autosomal Trisomy Syndromes: A Detailed Study of 27 Cases of Edwards' Syndrome and 27 Cases of Patau's Syndrome
}

\author{
ANGELA I. TAYLOR \\ From the Paediatric Research Unit, Guy's Hospital Medical School, London S.E.1
}

The three autosomal trisomy syndromes, which appear to be specific and well documented, are Down's syndrome (trisomy 21), Edwards' syndrome (trisomy 18), and Patau's syndrome (trisomy 1315). Down's syndrome was decribed in 1866 (Down, 1866), and the chromosomal nature of the disorder was demonstrated by Lejeune, Turpin, and Gautier in 1959. The rarer Edwards' and Patau's syndromes were described only in 1960 by Edwards et al. (1960) and Patau et al. (1960). Down's syndrome is well known and will only be discussed where a comparison of the three syndromes is relevant.

Since 1960 many cases of Edwards' and Patau's syndromes have been reported: owing to the rarity of the two conditions, most described only one or two cases. Series of cases have been reported by Weiss, DiGeorge, and Baird (1962), Warkany et al. (1964), Taylor and Polani (1964), Giambattista and Jacobson (1965), Butler et al. (1965), Snodgrass et al. (1966), Conen, Erkman, and Metaxotou (1966), and Ricci et al. (1966), and study of these series of cases allows the spectrum of clinical signs of these conditions to be assessed.

Data have been collected in a standard fashion in order to assess the clinical overlap between the two syndromes, and to date 54 infants have been studied.

\section{Material and Methods}

The case material has been collected during the fiveyear period from 1962-1967 from the South East of England and part of East Anglia. In that part of the I area administered by the South East Metropolitan Regional Hospital Board, a survey of all N.H.S. live births has been in progress since June 1965 , so that from this date, data from the region can be referred to a specific population. Cases of suspected autosomal chromosome abnormality are notified to the Paediatric Research
Unit and then studied in standard fashion. With the exception of 6 , all 54 cases in this report have been seen by the author.

In all, 27 cases of Edwards' syndrome and 27 cases of Patau's syndrome were investigated and confirmed. Each of the 54 infants was assessed for 46 clinical and 24 post-mortem findings, irrespective of the initial clinical diagnosis. Any additional findings in individual subjects were also noted. When possible, blood was taken from the propositus and parents for full blood group analysis, and analysis of haemoglobins, haptoglobins, transferrins, and serum Gc groups. Each infant had a dermatoglyphic examination, and was photographed. Sex chromatin and chromosome studies were also carried out. Chromosome studies were done on peripheral blood leucocytes, and also, in some instances, on skin fibroblasts. In general, 20 cells from each tissue were counted, 5 of these being fully analysed. Blood smears were examined for the excess of granulocyte nuclear projections often found in Patau's syndrome (Powars, Rohde, and Graves, 1964). In a few instances a neurological examination of the infant was possible. Results of all these studies are presented in the Tables and in the individual case reports (see Appendix).

\section{Results}

Clinical findings are summarized in Table $I$, and presented in detail in the case reports. Of 46 features scored, 44 occur in both syndromes, a considerable degree of overlap. An attempt has been made to measure this overlap: the right-hand column of Table I gives the discriminating ratio, which is calculated as the percentage of Edwards' syndrome cases with features divided by the percentage of Patau's cases with the same features. Taking two arbitrary cut-off points at ratios $<0.5$ and $>1.5$, it is possible to separate 'Patau's' features, an area of major overlap, and 'Edwards"' features. Features separated in this fashion are presented in Table II. 
TABLE I

OCCURRENCE OF 46 FINDINGS IN 54 CASES

\begin{tabular}{|c|c|c|c|c|c|}
\hline & \multicolumn{2}{|c|}{ Occurrence } & \multirow{2}{*}{$\stackrel{\%}{\%}$ Edwards } & \multirow{2}{*}{$\begin{array}{c}\% \\
\text { Patau }\end{array}$} & \multirow{2}{*}{ 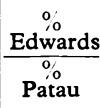 } \\
\hline & Edwards & Patau & & & \\
\hline $\begin{array}{l}\text { Feeding difficulty } \\
\text { Jaundice } \\
\text { Failure to thrive }\end{array}$ & $\begin{array}{r}26 / 27 \\
6 / 26 \\
26 / 27\end{array}$ & $\begin{array}{l}22 / 24 \\
11 / 26 \\
20 / 23\end{array}$ & $\begin{array}{l}96 \\
23 \\
96\end{array}$ & $\begin{array}{l}92 \\
42 \\
87\end{array}$ & $\begin{array}{l}1.04 \\
0.55 \\
1 \cdot 10\end{array}$ \\
\hline $\begin{array}{l}\text { Developmental } \\
\text { retardation } \\
\text { Hypertonia } \\
\text { Hypotonia } \\
\text { Jitteriness and apnoea } \\
\text { Seizures } \\
\text { Presumptive deafness } \\
\text { Cat-like cry } \\
\text { Microcephaly } \\
\text { Elongated skull } \\
\text { Ocular hypertelorism } \\
\text { Epicanthic folds } \\
\text { Microphthalmos } \\
\text { Eye defect } \\
\text { Iris colobomata } \\
\text { Strabismus } \\
\text { Low-set malformed }\end{array}$ & $\begin{array}{r}26 / 27 \\
13 / 26 \\
9 / 25 \\
11 / 24 \\
6 / 26 \\
5 / 15 \\
7 / 21 \\
2 / 25 \\
25 / 27 \\
21 / 26 \\
11 / 27 \\
7 / 26 \\
7 / 26 \\
0 / 25 \\
1 / 23\end{array}$ & $\begin{array}{r}26 / 26 \\
6 / 23 \\
11 / 23 \\
14 / 24 \\
6 / 24 \\
8 / 16 \\
1 / 23 \\
16 / 25 \\
4 / 25 \\
24 / 26 \\
14 / 25 \\
19 / 25 \\
23 / 26 \\
6 / 18 \\
1 / 15\end{array}$ & $\begin{array}{c}96 \\
50 \\
36 \\
46 \\
23 \\
33 \\
33 \\
8 \cdot 0 \\
93 \\
81 \\
41 \\
29 \\
29 \\
0 \\
4 \cdot 4\end{array}$ & $\begin{array}{c}100 \\
26 \\
48 \\
58 \\
25 \\
50 \\
4 \cdot 4 \\
64 \\
16 \\
92 \\
56 \\
76 \\
88 \\
33 \\
6.7\end{array}$ & $\begin{array}{l}0.96 \\
1.93 \\
0.75 \\
0.79 \\
0.92 \\
0.66 \\
7.5 \\
0.12 \\
5.8 \\
0.88 \\
0.73 \\
0.38 \\
0.33 \\
0 \\
0.66\end{array}$ \\
\hline $\begin{array}{l}\text { ears } \\
\text { Low-set normal ears } \\
\text { Hare-lip } \\
\text { Cleft palate } \\
\text { Micrognathia } \\
\text { Extra skin of nape } \\
\text { Webbed neck } \\
\text { Short neck }\end{array}$ & $\begin{array}{r}23 / 26 \\
1 / 26 \\
1 / 27 \\
3 / 27 \\
24 / 26 \\
15 / 27 \\
8 / 26 \\
16 / 26\end{array}$ & $\begin{array}{r}20 / 25 \\
3 / 25 \\
15 / 26 \\
18 / 26 \\
21 / 25 \\
13 / 22 \\
0 / 22 \\
19 / 24\end{array}$ & $\begin{array}{l}88 \\
3 \cdot 8 \\
3 \cdot 7 \\
11 \\
92 \\
56 \\
31 \\
62\end{array}$ & $\begin{array}{r}80 \\
12 \\
58 \\
69 \\
84 \\
59 \\
0 \\
79\end{array}$ & $\begin{array}{l}1 \cdot 1 \\
0.32 \\
0.06 \\
0 \cdot 16 \\
1 \cdot 1 \\
0.95 \\
0 \\
0 \cdot 79\end{array}$ \\
\hline $\begin{array}{l}\text { Capillary } \\
\text { haemangioma } \\
\text { Polydactyly } \\
\text { Partial syndactyly }\end{array}$ & $\begin{array}{l}5 / 26 \\
2 / 26 \\
8 / 25\end{array}$ & $\begin{array}{r}15 / 21 \\
19 / 25 \\
3 / 25\end{array}$ & $\begin{array}{c}19 \\
7 \cdot 7 \\
32\end{array}$ & $\begin{array}{l}72 \\
76 \\
12\end{array}$ & $\begin{array}{l}0 \cdot 26 \\
0 \cdot 1 \\
2 \cdot 7\end{array}$ \\
\hline $\begin{array}{l}\text { Distally implanted } \\
\text { thumb } \\
\text { Flexion deformity of }\end{array}$ & $12 / 23$ & $3 / 25$ & 52 & 12 & $4 \cdot 3$ \\
\hline $\begin{array}{l}\text { fingers } \\
\text { Hypoplastic nails } \\
\text { Long hyperconvex }\end{array}$ & $\begin{array}{l}23 / 26 \\
12 / 19\end{array}$ & $\begin{array}{r}17 / 25 \\
9 / 24\end{array}$ & $\begin{array}{l}89 \\
63\end{array}$ & $\begin{array}{l}68 \\
37\end{array}$ & $\begin{array}{l}1 \cdot 3 \\
1 \cdot 7\end{array}$ \\
\hline $\begin{array}{l}\text { nails } \\
\text { Retroflexible thumbs } \\
\text { Single palmar crease } \\
\text { Distal } t \text { triradius } \\
\text { Arches on finger-tips } \\
\text { Short dorsiflexed big }\end{array}$ & $\begin{array}{r}4 / 24 \\
11 / 22 \\
14 / 23 \\
12 / 21 \\
24 / 25\end{array}$ & $\begin{array}{r}17 / 25 \\
6 / 24 \\
16 / 25 \\
14 / 19 \\
7 / 21\end{array}$ & $\begin{array}{l}16 \\
50 \\
61 \\
57 \\
96\end{array}$ & $\begin{array}{l}68 \\
25 \\
64 \\
74 \\
33\end{array}$ & $\begin{array}{l}0 \cdot 24 \\
2 \cdot 0 \\
0 \cdot 95 \\
0 \cdot 89 \\
2 \cdot 9\end{array}$ \\
\hline $\begin{array}{l}\text { toe } \\
\text { Calcaneo-valgus feet } \\
\text { Equino-varus feet } \\
\text { Prominent calcaneus } \\
\text { Fibular S } \\
\text { Limited hip abduction }\end{array}$ & $\begin{array}{r}18 / 24 \\
13 / 25 \\
2 / 25 \\
20 / 26 \\
1 / 19 \\
17 / 25\end{array}$ & $\begin{array}{l}6 / 25 \\
2 / 23 \\
4 / 23 \\
7 / 25 \\
7 / 18 \\
4 / 21\end{array}$ & $\begin{array}{r}75 \\
52 \\
8 \\
77 \\
5 \\
68\end{array}$ & $\begin{array}{l}24 \\
8 \cdot 7 \\
17 \\
28 \\
39 \\
19\end{array}$ & $\begin{array}{l}3 \cdot 1 \\
6 \cdot 0 \\
0 \cdot 47 \\
2 \cdot 7 \\
0 \cdot 12 \\
3 \cdot 6\end{array}$ \\
\hline $\begin{array}{l}\text { Abnormal shoulder } \\
\text { abduction } \\
\text { Short sternum }\end{array}$ & $\begin{array}{r}3 / 24 \\
18 / 26\end{array}$ & $\begin{array}{l}1 / 21 \\
3 / 24\end{array}$ & $\begin{array}{l}12 \cdot 5 \\
68\end{array}$ & $\begin{array}{r}4 \cdot 8 \\
12 \cdot 5\end{array}$ & $\begin{array}{l}2 \cdot 6 \\
5 \cdot 4\end{array}$ \\
\hline $\begin{array}{l}\text { Inguinal/umbilical } \\
\text { hernia } \\
\text { Congenital heart }\end{array}$ & $6 / 27$ & $10 / 25$ & 22 & 40 & 0.55 \\
\hline $\begin{array}{l}\text { disease } \\
\text { Undescended testes }\end{array}$ & $\begin{array}{r}22 / 26 \\
4 / 4 \delta\end{array}$ & $\begin{array}{l}19 / 26 \\
13 / 140\end{array}$ & $\begin{array}{r}85 \\
100\end{array}$ & $\begin{array}{l}73 \\
93\end{array}$ & $\begin{array}{l}1 \cdot 1 \\
1 \cdot 07\end{array}$ \\
\hline
\end{tabular}

Necropsies were not always possible and were difficult to standardize. Abstracts are presented in the individual case reports and a discriminating separation is attempted in Tables III and IV.

Birth and Survival Data. Data from this series are presented in Table A (see Appendix). Partial birth and survival data on 153 cases of Edwards' syndrome and 74 cases of Patau's syndrome, mainly from the literature but including 25 cases of Edwards' syndrome and 24 cases of Patau's syndrome from this series, are presented in Table V.
TABLE II

DISCRIMINATING FEATURES OF EDWARDS' AND PATAU'S SYNDROMES ${ }^{\star}$

\begin{tabular}{|c|c|c|}
\hline $\begin{array}{c}\text { Ratio }<0.5 \\
\text { Patau's Features }\end{array}$ & $\begin{array}{l}\text { Ratio } 0.5-1 \cdot 5 \\
\text { Area of Major } \\
\text { Overlap }\end{array}$ & $\begin{array}{c}\text { Ratio }>1.5 \\
\text { Edwards' Features }\end{array}$ \\
\hline $\begin{array}{l}\text { Microcephaly } \\
\text { Eye defects } \\
\text { Microphthalmos } \\
\text { Iris colobomatat } \\
\text { Low-set normal } \\
\text { ears } \\
\text { Hare-lip } \\
\text { Cleft palate } \\
\text { Capillary } \\
\text { haemangioma } \\
\text { Polydactyly } \\
\text { Long hyperconvex } \\
\text { finger-nails } \\
\text { Talipes equino- } \\
\text { varus } \\
\text { Fibular S-shaped } \\
\text { hallucal arch }\end{array}$ & $\begin{array}{l}\text { Feeding difficulty } \\
\text { Jaundice } \\
\text { Developmental } \\
\text { retardation } \\
\text { Failure to thrive } \\
\text { Hypotonia } \\
\text { Jitteriness and apnoea } \\
\text { Seizures } \\
\text { Ocular hypertelorism } \\
\text { Presumptive deafness } \\
\text { Epicanthic folds } \\
\text { Strabismus } \\
\text { Low-set malformed } \\
\text { ears } \\
\text { Micrognathia } \\
\text { Short neck } \\
\text { Extra skin of nape } \\
\text { Flexion deformity of } \\
\text { fingers } \\
\text { Single palmar crease } \\
\text { Distal } t \text { triradius } \\
\text { Inguinal/umbilical } \\
\text { hernia } \\
\text { Congenital heart } \\
\text { disease } \\
\text { Undescended testes }\end{array}$ & $\begin{array}{l}\text { Hypertonia } \\
\text { Elongated (a-p) skull } \\
\text { Webbed neckt } \\
\text { Partial syndactyly } \\
\text { Distally implanted } \\
\text { thumb } \\
\text { Retroflexible thumb } \\
\text { Hypoplasia of nails } \\
\text { Short dorsiflexed big } \\
\text { toes } \\
\text { Talipes calcaneo- } \\
\text { valgus } \\
\text { Prominent calcaneus } \\
\text { Limited hip } \\
\text { abduction } \\
\text { Abnormal shoulder } \\
\text { abduction } \\
\text { Short sternum or } \\
\text { shield chest } \\
\text { High-pitched cat-like } \\
\text { cry } \\
\text { Simple arches on } \\
\text { finger-tips }\end{array}$ \\
\hline
\end{tabular}

* Note: 27 cases of Edwards' syndrome and 27 cases of Patau's syndrome were scored for the same 46 features. The discriminating ratio is calculated as: \% of Edwards' cases with feature.

t Features marked thus are the only features that do not appear in $\vec{c}$ both syndromes.

Pregnancy Order. No effect of pregnane order on the frequencies of these syndromes has been detected. Up to and including the propositi, the mothers of children with Edwards' syndrome in this series have had 73 pregnancies, of which $7 \circ$ $(9.6 \%)$ ended in known abortions. The mothers of $\overrightarrow{\overline{0}}$ children with Patau's syndrome have had 68 pregnancies, of which $5(7.4 \%)$ ended in known abortions. Assuming that $15 \%$ of all pregnancies end in spontaneous abortion (Carr, 1965), the proportion of abortions in this series may be lower than normal.

Maternal Age. In Edwards' syndrome and Patau's syndrome maternal age is raised, and birth $₹$ order is inevitably correlated with maternal age, but o there are not sufficient data to separate the effects of these two factors.

Maternal and paternal ages are inevitably correlated.

Survival. Very few infants with these two con- స్ట ditions survive the first six months of life. Survival is related to the severity of the congenital malforma- 6 tions and, to some extent, to the availability of paediatric care.

Season of Birth. This series indicates an ex- 
TABLE III

OCCURRENCE OF 24 POST-MORTEM FINDINGS IN 39 CASES

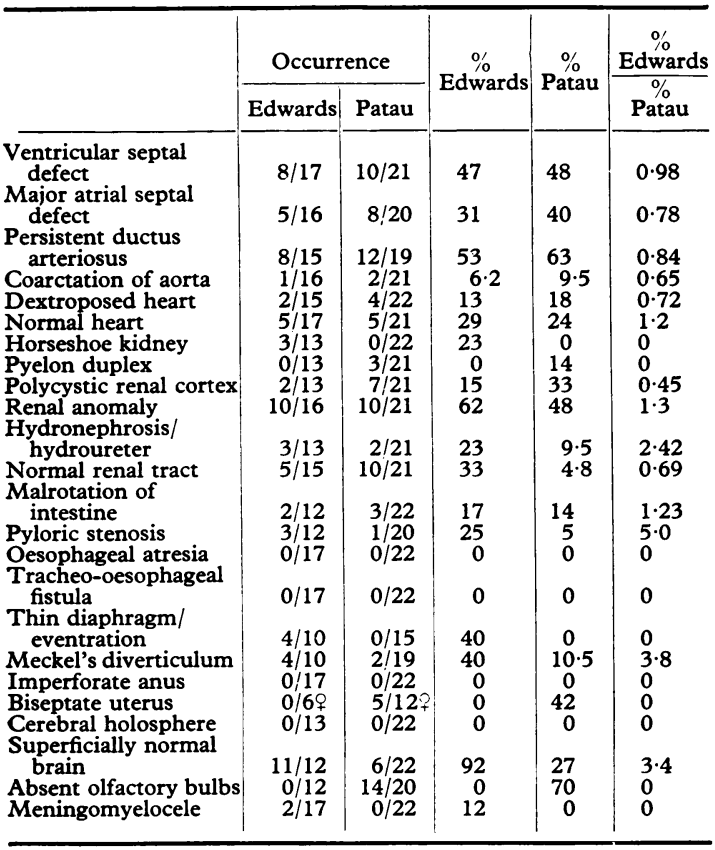

cess of winter conceptions. Although the data are small, the same trend is seen in six successive years (Table VI). $66.6 \%$ of all cases of Edwards' syndrome and $79 \%$ of all cases of Patau's syndrome

TABLE IV

DISCRIMINATING POST-MORTEM FINDINGS OF EDWARDS' AND PATAU'S SYNDROMES ${ }^{\star}$

\begin{tabular}{c|c|c}
\hline $\begin{array}{c}\text { Ratio <0.5 } \\
\text { Patau's Features }\end{array}$ & \multicolumn{1}{|c|}{$\begin{array}{c}\text { Ratio 0.5-1.5 } \\
\text { Area of Major } \\
\text { Overlap }\end{array}$} & $\begin{array}{c}\text { Ratio }>1.5 \\
\text { Edward's Features }\end{array}$ \\
\hline $\begin{array}{c}\text { Pyelon duplext } \\
\text { Polycystic renal } \\
\text { cortex } \\
\begin{array}{c}\text { Biseptate uterust } \\
\text { Absent olfactory } \\
\text { bulbst }\end{array}\end{array}$ & $\begin{array}{l}\text { Ventricular septal } \\
\text { defect } \\
\text { Major atrial septal } \\
\text { defect } \\
\text { Persistent ductus } \\
\text { arteriosus } \\
\text { Coarctation of aorta } \\
\text { Dextroposed heart } \\
\text { Normal heart } \\
\text { Normal renal tract } \\
\text { Malrotation of } \\
\text { intestine } \\
\text { Renal anomaly }\end{array}$ & $\begin{array}{l}\text { Horseshoe kidneyt } \\
\text { Hydronephrosis/ } \\
\text { hydroureter } \\
\text { Thin diaphragm/ } \\
\text { eventrationt } \\
\text { Meckel's } \\
\text { diverticulum } \\
\text { Superficially normal } \\
\text { brain } \\
\text { Meningomyelocelet } \\
\text { Pyloric stenosis }\end{array}$ \\
\hline
\end{tabular}

* Note: 18 cases of Edwards' syndrome and 21 cases of Patau's syndrome were scored for the same 24 findings. Four findings, though of rare occurrence in these syndromes, were absent in this series. Of the remainder, the discriminating ratio is calculated as:

$$
\% \text { of Edwards' cases with feature }
$$

† Finding exclusive to either syndrome. Four findings were negative in the present series: oesophageal atresia, tracheo-oesophageal fistula, imperforate anus, and cerebral holosphere.

TABLE V

BIRTH AND SURVIVAL DATA MAINLY FROM THE LITERATURE`

153 cases of Edwards' syndrome

Maternal age at birth (years)

Paternal age at birth (years)

Gestation age (weeks)

Birthweight (g.)

Survival (days)

$$
\begin{array}{ccc}
\text { Mean } \pm \text { S.E. } & 31 \cdot 7 \pm 0 \cdot 7 \\
\text { " " } & \text { ", } & 34 \cdot 9 \pm 0 \cdot 8 \\
\text { " " } & 42 \cdot 2 \pm 0 \cdot 8 \\
\text { " " } & 2242 \cdot 6 \pm 35.0 \\
\text { " } & \text { " } & 70 \cdot 85 \pm 21 \cdot 5 \\
& & \text { (variance ex- } \\
& & \text { ceeds mean) }
\end{array}
$$

Survival modes are at $<20$ and $>80$ days

Sex: $113 \circ: 30{ }^{*}$ Actually: $109 \mathrm{XX}: 4 \mathrm{XXX}: 27 \mathrm{XY}: 3 \mathrm{XXY}$

74 cases of Patau's syndrome

\begin{tabular}{l|ll} 
Maternal age at birth (years) & Mean \pm S.E. & $31.6 \pm 0.8$
\end{tabular}

Paternal age at birth (years) ", " " $31.9 \pm 1.0$

$\begin{array}{llll}\text { Gestation age (weeks) } & \text { " }, ~ & 39.0 \pm 0.3\end{array}$

Birthweight (g.)

Survival (days)

, , 2609.9 266.7

" " $89 \cdot 2 \pm 29 \cdot 9$

(variance ex-

ceeds mean)

Survival mode is at $<20$ days Sex: $35 \circ: 29 \sigma^{\circ}$

References: *Aisters-Bauer and Kleinhenz, 1963; Atkins and Rosenthal, 1961; Babini, Piazzi, and Scorza, 1962; Blanck et al., 1964 ; Bühler et al., 1962; Butler et al., 1965; Conen, Phillips, and Mauntner, 1962; Edwards et al., 1960; Ellis and Marwood, 1961 Finley, Finley, and Carte, 1963; German et al., 1962; Gottlieb et al., 1962; Habedank, 1964, Hansen et al., 1963; Haylock et al., 1963; Hecht et al., 1963b; Heinrichs and Allen, 1963; Holman et al. 1963; Hook et al., 1965; Huehns et al., 1964; Hustinx et al., 1964 Koenig, Lubs, and Brandt, 1962; Lafourcade et al., 1964 ; Lejeune, Delthil, and Berger, 1963; Levkoff, Mather, and Eisenstein, 1964 Lewis, 1964; Lewis and Faint, 1965; Lewis and Haas, 1965; Lubs, Koenig, and Brandt, 1961; McKusick, 1961; Marden et al., 1964; Marin-Padilla, Hoefnagel, and Benirschke, 1964; Méhes and Bata, 1965; J. Q. Miller et al., 1962, 1963; M. Miller et al., 1963 Nakagome, Komiya, and Arima, 1963; Naujoks and Carrasco, 1964 Neimann et al., 1964; Nigro, Franceschini, and Volante, 1964; Northcutt, 1962; Patau et al., 1960, 1961; Pfeiffer, 1964; Powars et al. 1964; Prader, 1962; Ricci and Borgatti, 1963; Rohde, Hodgman, and Cleland, 1964; Rosenfeld et al., 1962; Saraux et al., 1964; Schade, Schoeller, and Schultze, 1962; Schärer, Hauschtek, and Münlethaler, 1962; Scherz, 1966; Seki and Strauss, 1964; Sergovich et al., 1963; Smith et al., 1960, 1962, 1963; Steinberg and Jackson, 1963; Stewart and Bowles, 1963; Taylor and Polani, 1964; Therman et al., 1961; Tolksdorf et al., 1963; Tönz et al., 1965; Townes et al., 1962a, b; Trowell and Hilton, 1963; Turner, Dulk, and Watkins, 1964; Uchida, Bowman, and Wang, 1962a; Uchida et al., 1962b; Van Wijck et al., 1961; Voorhess, Aspillaga, and Gardner, 1964; Wagshal-Ives and Berman, 1963; Warburg and Mikkelsen, 1963; Weber et al., 1964; Weichsel and Luzzatti, 1965; Weiss et al., 1962; Windmiller et al., 1965; Zellweger, Beck, and Hawtrey, 1964.

were conceived between September and February. The mean maternal ages differ in the winter and summer conceived groups. In Edwards' syndrome the summer conceived group had a mean maternal age of $25 \cdot 2 \pm 1 \cdot 3$, compared with $31 \cdot 8 \pm 1 \cdot 7$ in the winter group. In Patau's syndrome the summer conceived group had a mean maternal age of $28.6 \pm$ $2 \cdot 9$, compared with $32.7 \pm 1.8$ in the winter group.

Sex Proportions. The sex proportions in Edwards' syndrome are grossly abnormal. Of 143 
TABLE VI

SEASON OF BIRTH IN EDWARDS' AND PATAU'S SYNDROME: CASES FROM SOUTH EAST ENGLAND $1961-67$

\begin{tabular}{|c|c|c|}
\hline Year & $\begin{array}{l}\text { Born } 1 \text { Jan.-31 May and } \\
1-31 \text { Dec. } \\
\text { Conceived Mar.-Aug. }\end{array}$ & $\begin{array}{l}\text { Born } 1 \text { Jun.-30 Nov. } \\
\text { Conceived Sep.-Feb. }\end{array}$ \\
\hline $\begin{array}{l}1961 \\
1962 \\
1963 \\
1964 \\
1965 \\
1966 \\
1967\end{array}$ & $\begin{array}{ll}1 & \text { Edward } \\
1 & \\
1 & \\
2 & \\
2 & \\
2 & \end{array}$ & $\begin{array}{l}\overline{1} \\
2 \\
1 \\
4 \\
3 \\
7\end{array}$ \\
\hline Totals & 9 & 18 \\
\hline $\begin{array}{l}1961 \\
1962 \\
1963 \\
1964 \\
1965 \\
1966 \\
1967\end{array}$ & $\begin{array}{l}=\quad \text { Patau' } \\
\overline{\frac{1}{1}} \\
\frac{1}{1} \\
\frac{1}{4}\end{array}$ & $\begin{array}{l}\overline{1} \\
2 \\
2 \\
4 \\
5 \\
7\end{array}$ \\
\hline Totals & 7 & 21 \\
\hline
\end{tabular}

cases, $113(77 \cdot 0 \%)$ were female. Within this group an unexpectedly high proportion of double aneuploids occurs: four $48, \mathrm{XXX}, 18+$ females and three

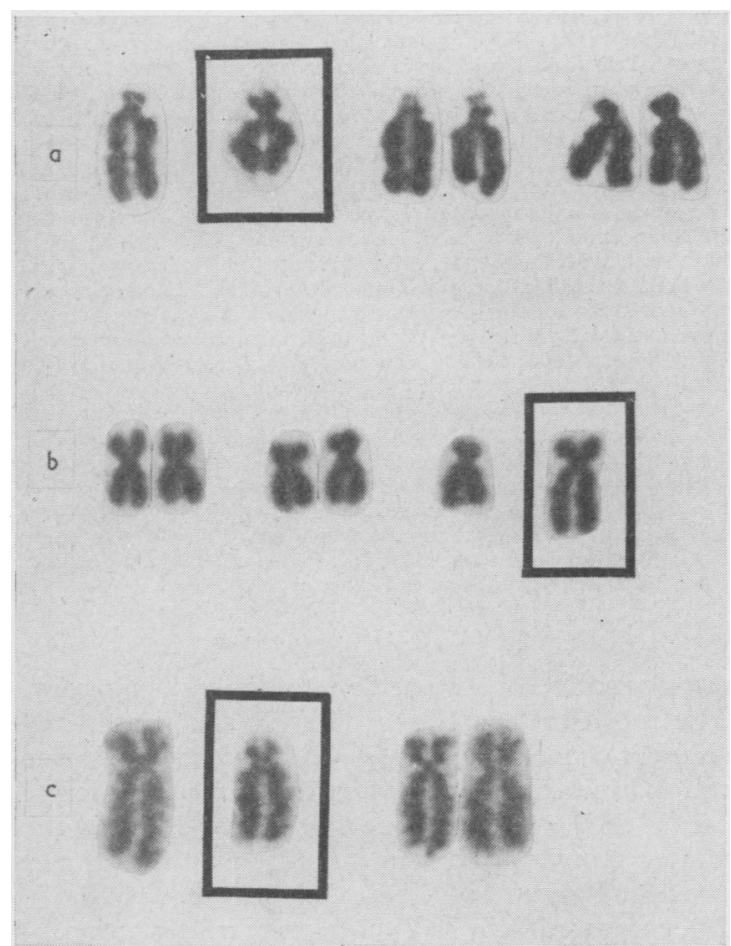

Fig. 1. Partial karyotype of 3 cases with structurally abnormal chromosomes. (a) D group showing (Dq-) in GH 051267/4308; (b) E group showing $(18-, ? 18 p+q+)$ in ES 231265/3020; (c) B group showing (Bp - ) in LB 290367/3855.
$48, \mathrm{XXY}, 18+$ males. The discrepancy between liveborn males and females is not accounted for by the reverse situation in abortions; of 6 reported 1718 trisomic abortions, 4 were female and 2 were male (Aisters-Bauer and Kleinhenz, 1963; Carr, $\overline{\bar{n}}$ 1963; Thiede and Salm, 1964; Szulman, 1965). J. L. Hamerton (personal communication, 1965) suggested that males and females might have different postnatal survival values. In 21 females and 4 males, mean survivals are 134.5 and 14.7 days, respectively, so there is a difference. However, the number of males is small and, as pointed out above, survival is determined by availability of paediatric care and actual policy concerning treatment, though this should not be expected to differ between the .sexes.

The sex proportion in Patau's syndrome is much nearer to normal, and mean survival is similar in the sexes, but still longer in females, 38.0 days as opposed to $22 \cdot 7$ days in males.

Chromosomal Findings. Of 27 cases of $\vec{c}$ Edwards' syndrome, 21 (78\%) had primary trisomy 18 , and $2(7 \cdot 4 \%)$ were double aneuploids with XXX and XXY sex chromosomes respectively $(4.8 \%$ of females and $20 \%$ of males). One (3.7\%) had 46 chromosomes with only 1 chromosome 18 and an $\vec{\varnothing}$ extra, structurally abnormal medium-sized chrog mosome (46,XX,E - , ?Ep+q+) (Fig. 1), 2 (7.4\% were mosaics, and $1(3.7 \%)$ had normal chromof somes.

Of 27 cases of Patau's syndrome, $19(70.4 \%)$ had primary trisomy $13-15(\mathrm{D}), 3(11 \cdot 1 \%)$ had D/D interchange $\mathrm{D}$ trisomy, $1(3.7 \%)$ was a mosaic, 1 $(3.7 \%)$ had 46 chromosomes with a deleted short arm of a B chromosome (46,XY,Bp-) (Fig. 1), and $2(7.4 \%)$ had normal chromosomes. One girl with absolutely typical features of Patau's syndrome (see Fig. 3h) had 46 chromosomes with a deletion of about half the long arm of a D chromosome (46,XX,Dq-) (Fig. 1). Cytogenetic findings in the propositi and most of their parents are summarized in Tables VII and VIII, and the complex structurally abnormal karyotypes in Fig. 1. (Cytogenetic results are described as recommended by the Chicago Conference (1966).)

Dermatoglyphs. Dermatoglyphic abnormali- $N$ ties are very common in both syndromes. Exami- N nation of the fingertips and palms is usually $N$ difficult, especially when the fingers are abnormally flexed. The fingers and palms are inspected using an auriscope, and the fingertip patterns and positions of the palmar triradii are noted. Prints of the soles are usually feasible.

Of 25 patients with Edwards' syndrome, 24 had

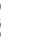


TABLE VII

CYTOGENETIC FINDINGS IN 27 CASES OF EDWARDS' SYNDROME WITH FAMILY STUDIES WHERE COMPLETED

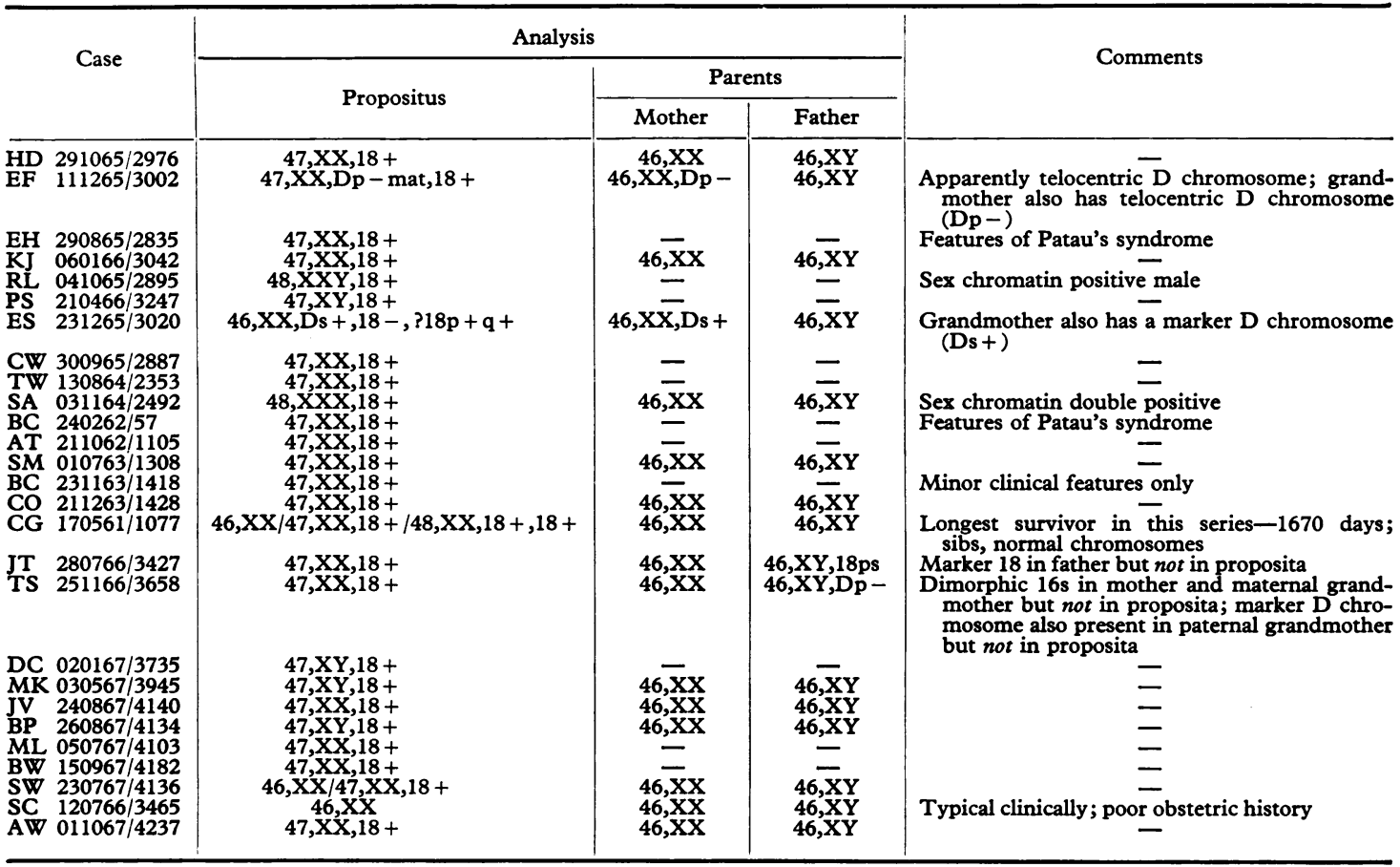

TABLE VIII

CYTOGENETIC FINDINGS IN 27 CASES OF PATAU'S SYNDROME WITH FAMILY STUDIES WHERE COMPLETED

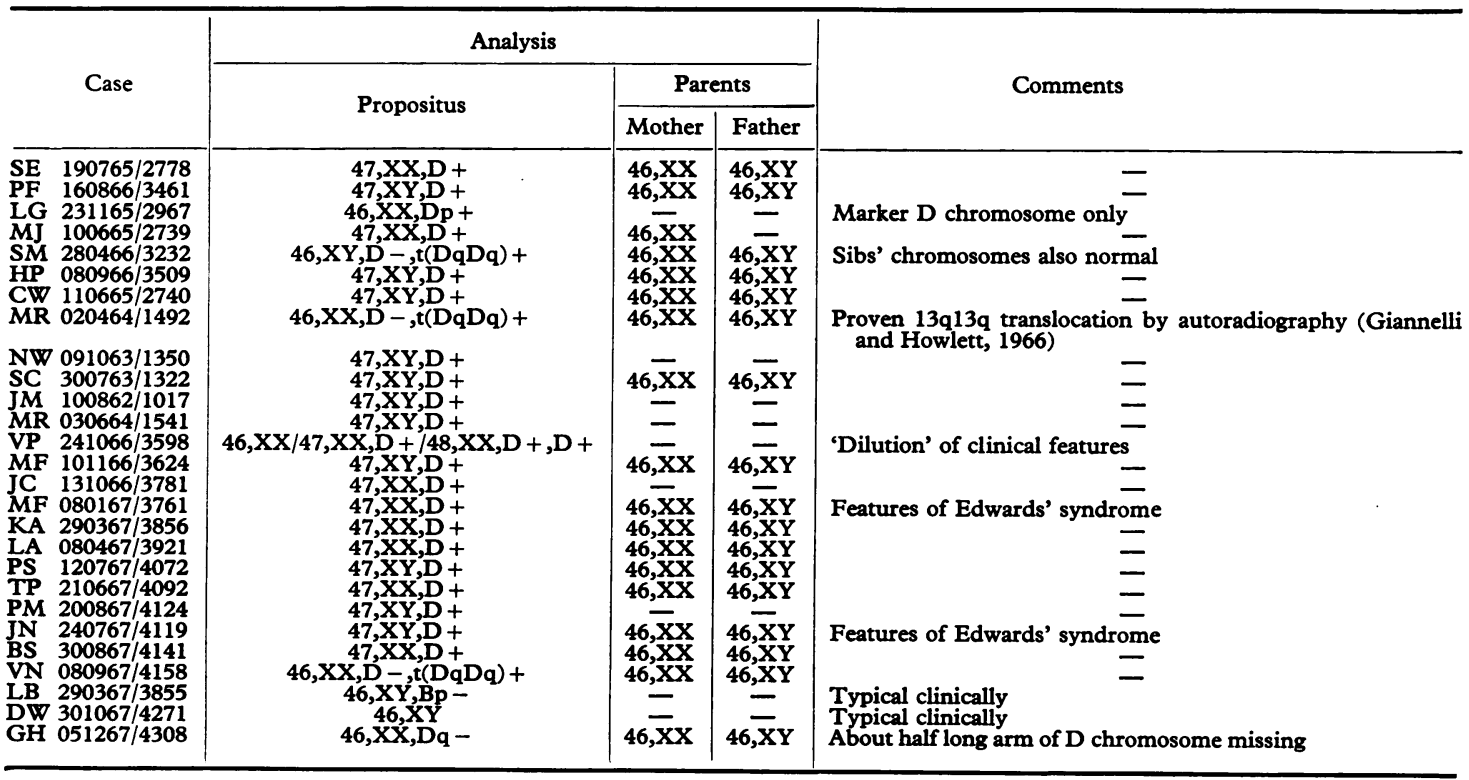


at least 3 simple arches on fingertips and often 10 . Partial or total dysplasia of the dermal ridges is a frequent finding. Three or more simple arches were also seen in 7 out of 21 cases of Patau's syndrome.

A distally placed $t$ triradius occurred in 12 out of 21 cases of Edwards' and 14 out of 20 cases of Patau's syndromes. In a few instances all or part of the palm was dysplastic, and in the remainder the triradii were normally situated.

A fibular S-shaped hallucal arch was present in 7 out of 18 cases of Patau's syndrome and in 1 out of 20 cases of Edwards' syndrome. Recently, Penrose has pointed out that a fibular S-shaped hallucal arch is not the most frequent finding in Patau's syndrome. The more typical configuration found in 13 of 28 cases is a tibial loop in the proximal thenar region associated with an $f$ triradius (Penrose, 1966).

TABLE IX

POPULATION INCIDENCE OF EDWARDS' AND PATAU'S SYNDROMES

\begin{tabular}{|c|c|c|c|c|}
\hline \multirow[t]{2}{*}{ Author } & \multicolumn{2}{|c|}{$\begin{array}{l}\text { No. of Newborns } \\
\text { Ascertained }\end{array}$} & \multicolumn{2}{|c|}{ No. of Cases } \\
\hline & Edwards & Patau & Edwards & Patau \\
\hline $\begin{array}{l}\text { Hecht et al. (1963b) } \\
\text { Smith (1964) } \\
\text { Taylor and Moores (1967) } \\
\text { A. I. Taylor and J. A. } \\
\text { Fraser Roberts } \\
\text { (unpublished) }\end{array}$ & $\begin{array}{r}999 \\
10,345 \\
9,688 \\
94,000\end{array}$ & $\begin{array}{r}1 \overline{0,345} \\
9,688 \\
94,000\end{array}$ & $\begin{array}{l}2 \\
3 \\
1\end{array}$ & $\overline{2}$ \\
\hline Totals & 115,032 & 114,033 & 17 & 15 \\
\hline Rates & & & $\begin{array}{l}1 \text { per } \\
6766\end{array}$ & $\begin{array}{l}1 \text { per } \\
7602\end{array}$ \\
\hline
\end{tabular}

Birth Frequencies. The highest estimate of the incidence of Edwards' syndrome is that of Hecht et al. (1963b) who reported 2 cases in 999 newborns. Marden, Smith, and McDonald (1964) found 1 case in 4412 newborns, and Smith (1964) extended the same survey for another 2 years, finding 3 cases in 10,345 newborns. Conen and Erkman (1966b) found 8 cases in 89,309 live births, and after complex adjustments for missed cases estimated the incidence as 1 per 4500 . Combining the data of Hecht et al.(1963b), Smith (1964), Taylor and Moores (1967), and A. I. Taylor and J. Fraser Roberts (unpublished) allows an assessment of incidence based on data from newborn populations where total ascertainment was attempted. This estimate is a minimum one and is 1 per 6766 live births (see Table IX).

With the exception of Hecht et al. (1963b), the same authors have estimated the incidence of Patau's syndrome. Marden et al. (1964) reported 2 cases in 4412 newborns and the extension of the $\frac{\mathbb{2}}{2}$ same survey to 10,345 newborns revealed no more $\stackrel{\mathbb{D}}{\overparen{D}}$ cases (Smith, 1964). Conen and Erkman (1966a) $\stackrel{\oplus}{\oplus}$ found 5 in 224,460 live births, and after corrections estimated the incidence of Patau's syndrome as $1 \stackrel{\text { ? }}{?}$ per 14,500. Taylor and Moores (1967) found 2 을 among 9688 newborns, and the survey in progress in 을 South East England has yielded 11 cases in 94,000 live births (A. I. Taylor and J. Fraser Roberts un- $\mathbb{\triangle}$ published). The incidence of Patau's syndrome in $\%$ newborns is 1 per 7602 live births (see Table IX).

\section{Discussion}

Clinical Features. Both syndromes are clinical entities though there is a considerable degree of over- 0 lap of features. Individuals with autosomal tri- in somy are known in other species, both plant and is animal. Generally these trisomics have a distinc- $N$ tive phenotype, but in drosophila the triplo-IV 은 individual cannot be distinguished by phenotype alone (Bridges, 1921). In Datura there are $12 \%$ chromosomes, and all theoretically possible $12 \frac{\mathbb{O}}{\mathrm{O}}$ trisomics are known (Blakeslee, 1928). All are phenotypically distinct and all are fertile. Similar considerations apply to the complex trisomics in Oenothera lamarckiana (Catcheside, 1936).

Autosomal trisomies in man determine marke variations from normal embryogenesis. The de. gree of overlap in the two syndromes is considerabfoand this is probably related to the times of disturbance of embryogenesis. The characteristic features are presumably determined by specific effects of the chromosomes involved. Most cases have a distinct facies which allows a rapid diagnosis, but a minority of cases have an intermediate facies (Fig. 2 and 3), and full clinical appraisal is needed to establish diagnosis. Each syndrome also has features in common with Down's syndrome (trisomy 21), but the facies of Down's syndrome is quite different. In Tables I and II a preliminary attempt is made to assess the degree of overlap in Edwards' and Patau's syndromes. In order to gain significant results, it is necessary to weight the individual features, and data are being assembled for a discriminant function analysis by computer.

Post-mortem findings are extremely variable. In some cases careful study reveals no abnormality, either microscopical or macroscopical, which was not detectable on clinical examination; in others, every system is demonstrably abnormal.

After a simple separation, the features that emerge as mainly 'Patau's features' are microcephaly, unspecified eye defects, microphthalmos, iris colobomata, low-set normal ears, hare-lip, and cleft palate. Also more frequently present in 


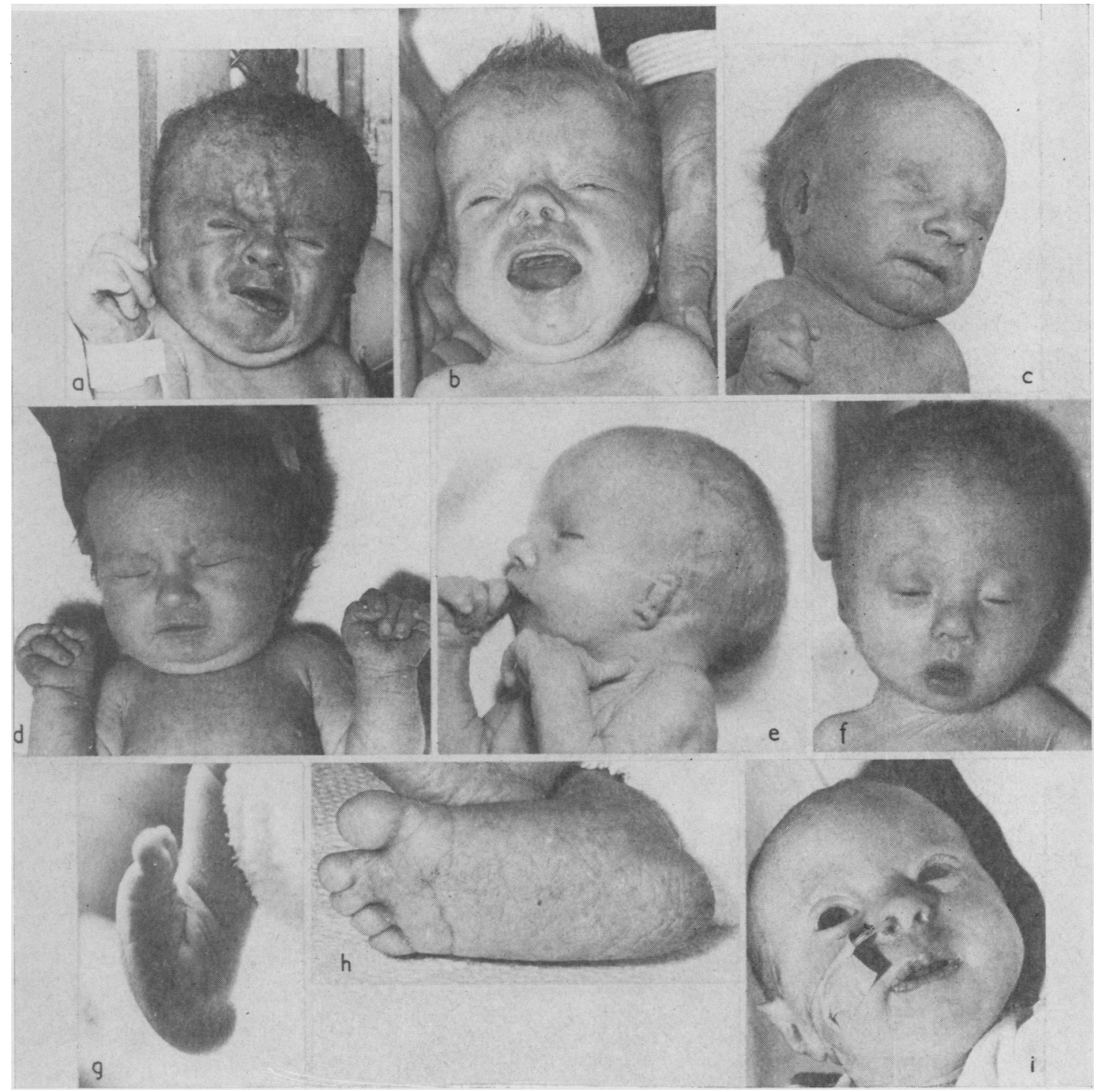

FIG. 2. Edwards' syndrome. (a) RL 041065/2895. 'Patau'-like facies with right facial palsy (48,XXY,18+); (b) SC 120766/3465, note dimple in chin $(46, \mathrm{XX})$; (c) DC 020167/3735, 'Patau'-like facies $(47, \mathrm{XY}, 18+$ ); (d) BW 150967/4182, typical posture; note axial deviation of fingers $(47, \mathrm{XX}, 18+$ ); (e) AT $211062 / 1105$, dolicocephaly and rudimentary ear pinna, also retroflexible left thumb $(47, \mathrm{XX}, 18+)$; (f) JV 240867/4140, rounded facies $(47, \mathrm{XX}, 18+)$; (g) DC 020167/3735, rocker-bottom foot $(47, \mathrm{XY}, 18+)$; (h) RL 041065/2895, sole showing short dorsiflexed hallux and toe syndactyly (48,XXY,18+); (i) SA 031164/2492, micrognathia, low-set ears $(48, \mathrm{XXX}, 18+)$.

Patau's syndrome are capillary haemangiomata, polydactyly, long hyperconvex fingernails, talipes equino-varus, and a fibular S-shaped hallucal arch. With the exception of iris colobomata all these findings occur also in Edwards' syndrome. 21 out of 46 findings occur with a similar frequency in both syndromes. Feeding difficulty is common though it may be due to different causes. In Edwards' syndrome the palate is deformed and is often partially paralysed, making sucking difficult or impossible. In Patau's syndrome severe clefts of the lip and palate often cause feeding problems. Developmental retardation is universal, and jaundice, hypotonia, and failure to thrive are common. Jitteriness, apnoeic attacks, and seizures are frequently found. Failure to respond to 'auditory attention' (a low tone sound stimulus of approximately $100 \mathrm{kc} / \mathrm{sec}$. which should result in an 


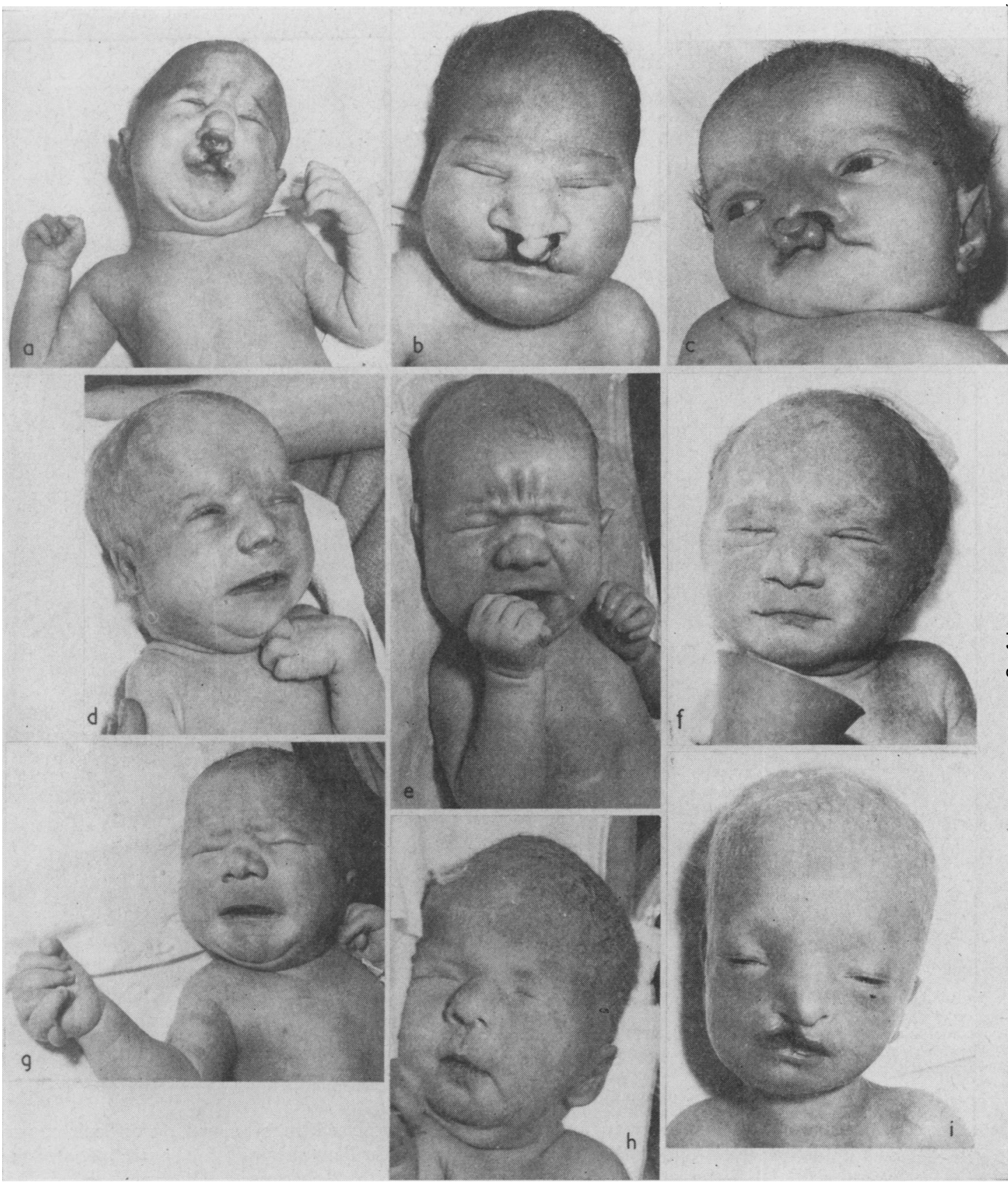

Fig. 3. Patau's syndrome (a) LA 080467/3921, microcephaly, severe cleft lip and palate (47,XX,D +); (b) PM 200867/4124, microcephaly, oblique palpebral fissures (47,XY,D +); (c) LG 231165/2967, hypertelorism, cleft lip, malformed ear (46,XX,Dp+); (d) MF $080167 / 3761$, intermediate facies, contracture of fingers $(47, X X, D+)$; (e) TP $210667 / 4092$, polydactyly $(47, X X, D+)$; (f) MR 020464/1492, 'old' face (46,XX,D - t(DqDq) +); (g) PS 120767/4072, low-set ears, micrognathia, polydactyly (47,XY,D +); (h) GH 051267/4308, typical face (46,XX,Dq-); (i) LB 290367/3855, hypertelorism, cleft lip (46,XY,Bp -). 
interruption in the crying cycle if the baby is crying) is common. This is a test of hearing and, to some extent, of cortical function. Facial features include ocular hypertelorism, epicanthic folds, strabismus, low-set malformed ears, and micrognathia. The neck is short with extra skin at the nape. Fingers show a flexion deformity with axial deviation and an overriding index finger. Inguinal and especially umbilical hernias are common. Males almost invariably have undescended testes, and often the penis is reduced in size. The external genitalia in females are somewhat ambiguous, with enlargement of the labia and clitoris, but not sufficiently to give rise to doubt about the sex of the infant. Congenital heart disease occurs quite often but a proportion of cases have normal hearts. Dermatoglyphic examination often reveals a distal $t$ triradius amd a single palmar crease, and here there is overlap with findings in Down's syndrome.

In the group of 'Edwards' syndrome features' are hypertonia, antero-posterior elongation of the skull, webbed neck, partial syndactyly of the toes, and distally implanted, often rudimentary, and retroflexible thumbs. The toe-nails are often hypoplastic. The halluces are often short, broad, and dorsiflexed. Feet often have a calcaneo-valgus deformity or a prominent calcaneus. Abnormal hip and shoulder abduction is common. The sternum is often short, and the chest may be narrow or shield shaped. There is often a high-pitched cry, probably due to an abnormally shaped palate and micrognathia. Simple arches on finger-tips are diagnostic. With the exception of neck webbing, all these features also occur in Patau's syndrome.

There is an even greater degree of overlap when the post-mortem findings are considered. Congenital heart disease is common, with major atrial and ventricular septal defects, dextroposition of the heart, coarctation of the aorta, pulmonary stenosis, and other defects. However the heart may be normal in either syndrome. Renal anomalies are quite common, and include cystic kidneys, double ureters, hydronephrosis, hydroureters, horseshoe kidneys, and unilateral absence of a kidney. A normal renal tract may also occur in both syndromes. Malrotation of the intestine occurs in both syndromes, and Meckel's diverticulum occurs more frequently in Edwards' syndrome, as does pyloric stenosis. A biseptate or bicornuate uterus occurs in Patau's syndrome, and in two cases in the present series the latter was associated with an absent ovary and tube.

The brain may be superficially normal in Edwards' syndrome or it may have abnormally few convolutions or dilated cerebral ventricles. In
Patau's syndrome the olfactory nerves are usually missing or, if present, are reduced in size. The optic nerves may be absent or very small. The corpus callosum is often abnormally small.

Maternal Age (see above). This is raised with similar mean values in all three autosomal trisomic syndromes. It is of interest to look at the shape of the age distribution curves (Fig. 4). In both Edwards' and Down's syndrome the curve is markedly bimodal. The peaks are at 20-24 and 35-39 years in Edwards' syndrome, and 25-29 and 35-39 years in Down's syndrome (Richards, 1967). So in both these conditions there is a large group of maternal age-independent births. Ageing of cells in the ovary, with consequent reduced meiotic efficiency, is a possible reason for the increased risk of chromosomally abnormal offspring with advancing age. Chromosome studies on populations suggest that even mitotic efficiency is reduced with age (Jacobs et al., 1963; Hamerton et al., 1965). In the maternal age-independent group of Down's syndrome cases, there is a concentration of those due to complex cytogenetic variants such as translocations and mosaicism. No such concentration is as yet apparent in the maternal age-independent group of Edwards' syndrome, but the data are much less. In Patau's syndrome the maternal age distribution is unimodal, with a very large peak at 2529 years. The curve has a slight kink at 40-44 years. However, the larger data of E. Magenis and F. Hecht (personal communication, 1967) of 172 cases have a much more bimodal distribution, with peaks at 25-29 and 35-39 years. It seems that a proportion of cases of Edwards' syndrome and a majority of those of Patau's syndrome are maternal age independent.

Seasonal Incidence. Clustering of cases in time has been reported in mongolism (Stoller and Collman, 1965) and has recently been described in Edwards' syndrome (Heinrichs, Allen, and Nelson, 1963; Conen and Erkman, 1966b) and in Patau's syndrome (Conen and Erkman, 1966a).

The present series from South East England and East Anglia shows a seasonal incidence, with $67 \%$ of cases of Edwards' syndrome and $79 \%$ cases of Patau's syndrome born in June to November inclusive. The repetition of this trend over the six years studied to date, and the different mean maternal ages in the summer and winter conceived groups (see above), increases the probability that this is a real phenomenon. That the apparent excess of Edwards' and Patau's syndrome births in 

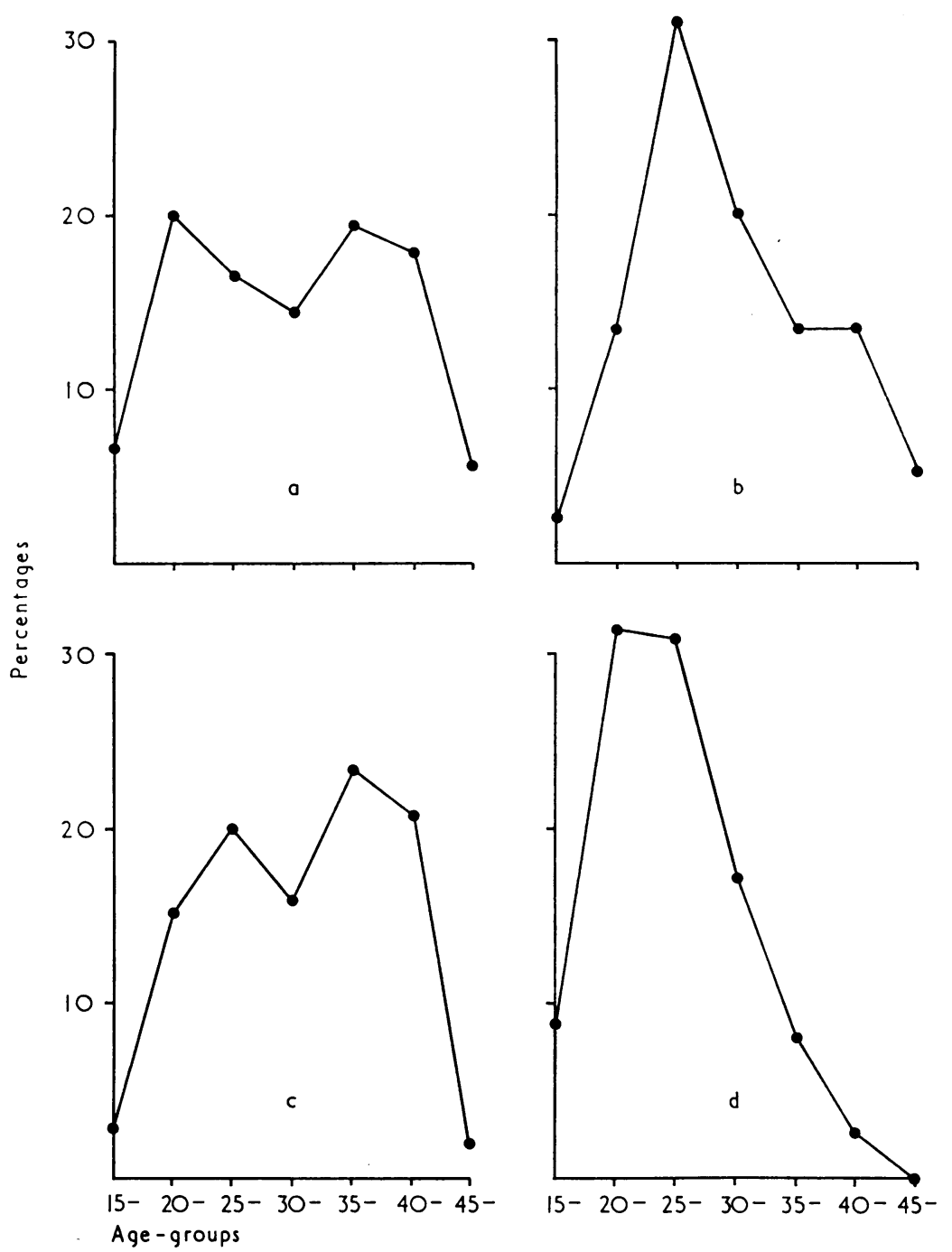

Fig. 4. Maternal age distribution in (a) Edwards' syndrome, (b) Patau's syndrome, (c) Down's syndrome, and (d) in the general population.

June to November is not due to an excess of total live births at this time is seen by inspection of the Registrar General's Quarterly Returns (Registrar General, 1966). Of 5,876,277 live births in the period 1960-66, 2,999,682 were in January-June. There were $2,876,597$ in July-December, which period compares most nearly with the JuneNovember period in the present series. Clustering in Conen and Erkman's series was mainly of January-June births in both syndromes, but regional clusters can probably only be related to environmental variations. Parents of the propositi were closely questioned about radiation and illnesses, especially near the time of conception, and there is no history of undue radiation exposure or viral or other illness in this series. If a viral infection is to be implicated, it must be a subclinical one.

Sex Proportions. The abnormal sex proportion in Edwards' syndrome is difficult to explain. The discrepancy between the sexes is so large that it must be the result of differential survival at some stage. As noted above, 17-18 trisomic abortions are extremely rare, and of 6 known, 4 were female. It is possible that male 18-trisomic foetuses are early resorptions or 'missed abortions', or even that Y-bearing sperm with two No. 18 chromosomes are poorly viable. 
Work on the T-locus in the mouse (Braden and Weiler, 1964) has shown that the genotype of the egg may influence the sex of the sperm that is able to fertilize it. It may be that a similar type of gametic selection is operating in man, and that a disomic-18 egg is more readily fertilized by an $\mathrm{X}$ bearing sperm.

Amongst infants with Edwards' syndrome, Conen and Erkman (1966b) demonstrate a significantly longer survival in females, and this is confirmed in the present series. Yet there is no difference in birth data in the sexes, and the females seen by the author are in no way less severely affected than the males. The longest survivor in the present series lived for 1670 days, but she was a mosaic with minor normal and tetrasomic cell lines. At the time of writing, two cases of Edwards' syndrome are still alive: a primary trisomic boy aged $3 \frac{1}{2}$ months, and a girl, also a primary trisomic, aged $2 \frac{1}{2}$ months.

Chromosomal Findings. Chromosome studies on children with clinical features of Edwards' and Patau's syndromes reveal a surprising variability of findings. In Down's syndrome about $6 \%$ of cases are due to complex cytogenetic variants such as translocations and mosaics (Richards, 1967). Down's syndrome with normal chromosomes is unknown. It is difficult to assess the frequency of 'complex' variants from the literature as they are more likely to be published singly than single cases of primary trisomy. The present series, selected on clinical grounds alone, allows a provisional estimate of these complex variants: $18.5 \%$ in Edwards' syndrome and $22.2 \%$ in Patau's syndrome.

Double aneuploids with $48, \mathrm{XXX}, 18+$ and $48, \mathrm{XXY}, 18+$ occur with an unexpectedly high frequency in Edwards' syndrome, in $3.5 \%$ of females and $10 \%$ of males. In Patau's syndrome $48, \mathrm{XXX}, \mathrm{D}+$ females are unknown, but there was a 6-8-week abortus with a $48, \mathrm{XXY}, \mathrm{D}+$ chromosome complement (Pergament and Kadotani, 1965). In Down's syndrome $48, \mathrm{XXX}, 21+$ is extremely rare. $48, \mathrm{XXY}, 21+$ occurs with a frequency of 1 in 11,614 live male births (Taylor and Moores, 1967).

Translocations or structural rearrangements of unknown origin are well known in the two syndromes (Brodie and Dallaire, 1962; Hecht et al., 1963a; Rohde, Lee, and Sapin, 1963; Therman et al., 1963) and many others. In the majority of cases these are not familial. In Patau's syndrome sporadic D/D translocations are common; 4 out of 9 in Conen and Erkman's (1966a) series and 3 out of 27 in this series. Familial transmission of a $D / D$ translocation chromosome is well known, but only very rarely does this lead to production of a child with $\mathrm{D} / \mathrm{D}$ translocation $\mathrm{D}$ trisomy (K. Hirschhorn and J. R. Miller personal communication to Conen et al., 1966). The majority of cases of Patau's syndrome with $\mathrm{D} / \mathrm{D}$ translocation $\mathrm{D}$ trisomy have parents with normal chromosomes.

One of the present cases of Patau's syndrome had 46 chromosomes and a normal D group but with a deletion of most of the short arm of one of the B chromosomes. A look at the literature reveals 6 further cases with a deleted B chromosome associated with features resembling Patau's syndrome or a 'midline syndrome' (Wolf et al., 1965; Miller et al., 1966; Sidbury, Schmickel, and Gray, 1964; Giorgi, Ceccarelli, and Paci, 1966; Hirschhorn, Cooper, and Firschein, 1965; Hijmans and Shearin, 1965). Autoradiographic studies on 2 of these cases showed that chromosome No. 4 was the deleted one (Wolf et al., 1965; Miller et al., 1966). A further case in this series had an apparent deletion of about half the long arm of a D chromosome, $46, \mathrm{XX}, \mathrm{Dq}-$. Mikelsaar (1967) has reported a child with many features of Patau's syndrome, who was a mosaic, 46,XY/46,XY,Dq - .

Mosaics occur in Edwards' and Patau's syndromes, and, as in Down's syndrome, there may be a 'dilution' of clinical features leading to increased difficulty in diagnosis. Though the mosaic cases may survive slightly longer, there is no real improvement in prognosis.

The most interesting cytogenetic finding in Edwards' and Patau's syndromes is that of normal chromosomes. Published reports are all too infrequent but include those of Hook and Yunis (1965), Marshall et al. (1964), Szotowa and Kowalewska (1965), and Burks and Sinkford (1964). In this series, 1 child with Edwards' syndrome and 2 children with Patau's syndrome had normal chromosomes. The child with Edwards' syndrome was typical in every sense, including the presence of simple arches on finger-tips. She had an older sib who died at the age of 5 days with multiple congenital anomalies, and who may also have had Edwards' syndrome. Both parents had normal chromosomes. It is possible that an unknown factor interfered at the appropriate stage of embryogenesis and produced phenocopies of Edwards' syndrome. Of the 2 children with Patau's syndrome and normal chromosomes, one had a marker $\mathrm{D}$ chromosome with an enlargement of the short arm $(46, \mathrm{XX}, \mathrm{Dp}+)$. It has not been possible to study the parents of either of these 2 children.

The occurrence of 'marker' chromosomes in 
children with Edwards' and Patau's syndromes and their families is worthy of comment. Among 27 cases of Edwards' syndrome, 2 had marker chromosomes, one with a $\mathrm{D}$ with very large satellites and one a telocentric $D$. In both cases the marker was present in at least one other generation. In addition, the father of a girl with primary 18-trisomy had a marker chromosome 18 in which the short arm appeared to be satellited $(46, X Y, 18 \mathrm{ps}+)$. This marker was not present in the proposita. In another case, also a girl with primary 18-trisomy, the baby's mother and maternal grandmother had unusually polymorphic No. 16 chromosomes. The baby's father and paternal grandmother had a D chromosome with deleted short arms. Neither of these two marker chromosomes was present in the proposita.

In the 27 cases of Patau's syndrome, the only marker was that discussed above, and was in a child with normal chromosomes. The marker chromosomes are regarded as within the normal range of variation and their incidence in a random adult population is $2-3 \%$ (Court Brown et al., 1966). In this small group of cases of Edwards' syndrome, the incidence of marker chromosomes is much higher than the population figure; this may be due to chance or to an increased risk of meiotic errors induced by the marker chromosome.

Blood Group and other Marker Gene Studies. These were undertaken in an attempt to locate gene loci on the trisomic chromosomes. To date, the results have been non-contributory.

An interesting finding is the occurrence in this series of two of the extremely rare instances of anomalous inheritance of $\mathrm{Xg}$ (Noades et al., 1966). MR 020464/1492, a case of Patau's syndrome with karyotype $46, \mathrm{XX}, \mathrm{D}-, \mathrm{t}(\mathrm{DqDq})+$, was $\mathrm{Xg}(\mathrm{a}-)$. Both parents were $\mathbf{X g}(\mathrm{a}+)$. Other blood groups showed no anomalies. CO 211263/1428, a case of Edwards' syndrome with $47, \mathrm{XX}, 18+$, was $\mathrm{Xg}(\mathrm{a}-)$, with an $\mathrm{Xg}(\mathrm{a}-)$ mother and an $\mathrm{Xg}(\mathrm{a}+)$ father. Paternity was confirmed by the occurrence of $\mathrm{Hb} \mathrm{D}$ Punjab in the proposita and her father; an extremely rare occurrence in this country (H. Lehmann, 1967, personal communication).

The majority of cases studied had high values of foetal $\mathrm{Hb}$, but most were tested within a few days of birth when such values are normal. Cases that survived longer showed an abnormal persistence of foetal $\mathrm{Hb}$; in LA $080467 / 3921$ the value was $50 \%$ at 2 months and $31 \%$ at 3 months, and in JN 240767/ 4119 the value was $80 \%$ at 1 month of age. This is further evidence of retarded embryonic develop- ment, with a delay in the switching on of adult haemoglobin synthesis.

Dermatoglyphs. Dermatoglyphic abnormalities are common in the two syndromes, and in $\overrightarrow{\vec{N}}$ general confirm the impression of retarded em- $O$ bryonic development, even to the extent of partial or total failure of dermal ridge development. Simple arches are the most striking finding, especially as they occur in Edwards' and Patau's syndromes, but not in Down's. Occurrence of a distal $t$ triradius is easier to understand as it results from delayed elongation of the hand, and is a common finding in Down's syndrome.

Studies on Spontaneous Abortion. Foetuses with 18-trisomy and 13-15-trisomy are known from studies of abortion material (Aisters-Bauer and Kleinhenz, 1963; Carr, 1965; El-Alf, Biesele, and Smith, 1964; Szulman, 1965; Thiede and Salm, 1964). Such foetuses are rare and are seldom sufficiently well preserved for anatomical studies. However, Singh and Carr (1967) studied a small group of foetuses with 13-15 trisomy and found none of the usual malformations of Patau's syndrome. There is much to suggest from these and other studies, however, that more of all threes trisomic concepti are lost as abortions than survive to live birth.

Identification of Trisomic Chromosomes. Autoradiographic studies have established the identity of the trisomic chromosome in Patau's syndrome as 13 or $D_{1}$ (Giannelli, 1965; Büchner, Pfeiffer, and Stupperich, 1965), and this has been confirmed by use of autoradiography combined with measurement (Giannelli and Howlett, 1966). Yunis, Hook, and Mayer (1964) were the first to demonstrate that Edwards' syndrome was associated with trisomy 18.

Live Birth Frequencies. Using data uncorrected for missed cases, both syndromes occur with a frequency of approximately 1 in 7000 live births, but these are minimum estimates, and further prospective studies on newborn populations will provide a more exact figure. Certainly the referral of equal numbers of each syndrome to the Paediatric Research Unit indicates that the incidence of the two conditions is similar.

\section{Summary}

Twenty-seven cases of Edwards' syndrome (trisomy 18) and 27 cases of Patau's syndrome (trisomy 13-15) are described in detail, with particular reference to overlap of clinical features. Birth and 
survival data are discussed and compared with larger data from the literature. The range of cytogenetic findings and the high frequency of complex variants are described. The population incidence of the two conditions is estimated.

I should like to thank all the paediatricians, obstetricians, and pathologists without whose help this study would have been impossible. Much of the material was derived from the survey of live births in the area administered by the South East Metropolitan Regional Hospital Board, and I am particularly grateful to the Consultants in this region for their prompt notification of cases and helpful co-operation. Cases were referred by: Drs. E. Addenbrooke, R. E. Bonham Carter, S. Carter, P. J. N. Cox, A. B. Donnison, M. Dynski-Klein, Mr. B. R. Eaton, Mr. H. B. Eckstein, Drs. O. D. Fisher, J. L. Greaves, M. H. K. Haggie, M. C. Joseph, S. J. R. Macoun, R. C. Mac Keith, T. P. Mann, R. H. MayonWhite, D. O. Morris, F. W. Nash, A. P. Norman, C. H. Nourse, T. E. Oppé, A. Robinson, T. S. Rodgers, L. G. Scott, C. E. Stroud, P. N. Swift, M. A. Warley, and D. A. J. Williamson. I should also like to thank all staffs of Maternity and Premature Baby Units for their help. Skilled, technical help was provided by Miss V. M. McGuire, Mrs. B. Scott, and Miss D. Garrett, and secretarial help by Miss B. J. Alexander, Miss S. Burnett, Mrs. J. L. Hinton, and Mrs. H. M. Aggett. Blood group, genetic marker, and haemoglobin studies were undertaken by Drs. R. Race, R. Sanger, E. Robson, and H. Lehmann. I am indebted to Mr. J. L. Hamerton, Professor P. E. Polani, and Dr. J. A. Fraser Roberts for their advice and constructive criticism. The work was supported by the Spastics Society and the Medical Research Council.

\section{REFERENCES}

Aisters-Bauer, V. L., and Kleinhenz, R. J. (1963). Chromosomes in 15 cases of congenital anomalies. Hum. Chromos. Newsl., No. 10, p. 5.

Atkins, L., and Rosenthal, M. K. (1961). Multiple congenital abnormalities associated with chromosomal trisomy. New Engl. 7. Med., 265, 314.

Babini, B., Piazzi, G., and Scorza, P. (1962). On a case of multiple congenital abnormalities with group 16-18 chromosome trisomy. Clin. pediat. (Bologna), 41, 684.

Blakeslee, A. F. (1928). Genetics of Datura. Verh. V. Internat. Kong. Vererb., $1,117$.

Blanck, C., Jalling, B., Lindsten, J., and Zetterqvist, P. (1964) Trisomy 13-15. Report of a case with clinical, cytogenetic and pathologic findings. Acta path. microbiol. scand., 60, 36.

Braden, A. W. H., and Weiler, H. (1964). Transmission ratios at the $T$-locus in the mouse: inter- and intra-male heterogeneity. Aust. f. biol. Sci., 17, 921.

Bridges, C. B. (1921). Genetical and cytological proof of nondisjunction of the fourth chromosome of Drosophila melanogaster. Proc. nat. Acad. Sci. (Wash.), 7, 182.

Brodie, H. R., and Dallaire, L. (1962). The E syndrome (trisomy 17-18) resulting from a maternal chromosomal translocation. Canad. med. Ass. F., 87, 559.

Büchner, T., Pfeiffer, R. A., and Stupperich, E. (1965). Reduplikationsverhalten der Chromosomen der Gruppe D (13-15) und Identifikation des Extrachromosoms bei Trisomie D. Klin. Wschr., 43, 19, 1062.

Bühler, E., Bodis, I., Rossier, R., and Stalder, G. (1962). Trisomy 13-15 with cebocephaly. Ann. paediat. (Basel), 199, 198.

Burks, J. L., and Sinkford, S. (1964). Clinical trisomy E syndrome (16-18): A cytogenetic enigma. Clin. Pediat. (Philad.), 3, 233.

Butler, L. J., Snodgrass, G. J. A. I., France, N. E., Sinclair, L., and Russell, A. (1965). E (16-18) trisomy syndrome: Analysis of 13 cases. Arch. Dis. Childh., 40, 600.
Carr, D. H. (1963). Chromosome studies in abortuses and stillborn infants. Lancet, 2, 603.

- (1965). Chromosome studies in spontaneous abortions. Obstet. and Gynec., 26, 308.

Catcheside, D. G. (1936). Origin, nature and breeding behaviour of Oenothera Lamarckiana trisomics. $\quad$ f. Genet., 33, 1 .

Chicago Conference (1966). Standardization in Human Cytogenetics. Birth Defects: Original Article Series II. National Foundation, March of Dimes, New York.

Conen, P. E., and Erkman, B. (1966a). Frequency and occurrence of chromosomal syndromes I. D-trisomy. Amer. F. hum. Genet., 18, 374 .

, and - (1966b). Frequency and occurrence of chromosomal syndromes II. E-trisomy. ibid., 18, 387.

,-- , and Metaxotou, C. (1966). The ' $D$ ' syndrome. Report of four trisomic and one D/D translocation case. Amer. F. Dis. Child., 111, 236.

, Phillips, K. G., and Mauntner, L. S. (1962). Multiple developmental anomalies and trisomy of a 13-15 group chromosome. ('D' syndrome). Canad. med. Ass. F., 87, 709.

Court Brown, W. M., Buckton, K. E., Jacobs, P. A., Tough, I. M., Kuenssberg, E. V., and Knox, J. D. E. (1966). Chromosome studies on adults. Eugenics Laboratory Memoirs, no. 42. Cambridge University Press, London.

Down, J. L. H. L. (1866). Observations on an ethnic classification of idiots. Lond. Hosp. Clin. Rep., iii, 259.

Edwards, J. H., Harnden, D. G., Cameron, A. H., Crosse, V. M., and Wolf, O. H. (1960). A new trisomic syndrome. Lancet, 1, 787.

El-Alfi, O. S., Biesele, J. J., and Smith, P. M. (1964). Trisomy-18 in a hydrocephalic fetus. F. Pediat., 65, 67.

Ellis, J. R., and Marwood, J. C. (1961). Autosomal trisomy syndromes. Lancet, 2, 263.

Finley, W. H., Finley, S. C., and Carte, E. T. (1963). 17-18 trisomy syndrome: review and report of a case. Amer. F. Dis. Child., 106, 591.

German, J. L., Rankin, J. K., Harrison, P. A., Donovan, D. J., Hogan, W. J., and Bearn, A. G. (1962). Autosomal trisomy of a group 16-18 chromosome. F. Pediat., 60, 503.

Giambattista, M. A., and Jacobson, C. B. (1965). A one-year cytogenetic survey in a children's hospital. Clin. Proc. Child. Hosp. (Wash.), 21, 217.

Giannelli, F. (1965). Autoradiographic identification of the D(1315) chromosome responsible for $D_{1}$ trisomic Patau's syndrome. Nature (Lond.), 208, 669.

, and Howlett, R. M. (1966). The identification of the chromosomes of the D group (13-15) Denver: An autoradiographic and measurement study. Cytogenetics, 5, 186.

Giorgi, P. L., Ceccarelli, M., and Paci, A. (1966). A case of cri du chat syndrome with peculiar phenotypic abnormalities. Minerva pediat., 17, 1972.

Gottlieb, M. I., Hirschhorn, K., Cooper, H. L., Lusskin, N., Moloshok, R. E., and Hodes, H. L. (1962). Trisomy-17 syndrome. Report of three cases and review of the literature. Amer. f. Med., 33, 763.

Habedank, M. (1964). The clinical diagnosis and differential diagnosis of trisomy 17-18. Ann. paediat. (Basel), 203, 428.

Hamerton, J. L., Taylor, A. I., Angell, R., and McGuire, V. M. (1965). Chromosome investigations of a small isolated human population: Chromosome abnormalities and distribution of chromosome counts according to age and sex among the population of Tristan da Cunha. Nature (Lond.), 206, 1232.

Hansen, H. G., Tolksdorf, M., Zinat-Bakhsh, H., Lehmann, W., Nitsch, K., and Weidemann, H. R. (1963). Malformation syndrome with trisomy amongst the chromosomes of the group 16-18. Hum. Chromos. Newsl., No. 9, p. 12.

Haylock, J., Fitzgerald, M., Danks, D., and Dennett, X. (1963). Two cases of the 18 trisomy syndrome, one in combination with an XXY karyotype. ibid., No. 9, p. 15.

Hecht, F., Bryant, J., Arakaki, D., Kaplan, E., and Gentile, G. (1963a). Trisomy-18 due to de-novo translocation. Lancet, 1 , 114.

,, Motulsky, A. G., and Gilbertt, E. R. (1963b). The no. 17-18 (E) trisomy syndrome. Studies on cytogenetics, dermatoglyphics, paternal age and linkage. $\mathcal{F}$. Pediat., 63, 605.

Heinrichs, E. H., and Allen, S. W. (1963). The 18-trisomy syndrome. Clin. Pediat. (Philad.), 2, 25.

, Allen, S. W., Jr., and Nelson, P. S. (1963). Simultaneous 18-trisomy and 21-trisomy cluster. Lancet, 2, 468. 
Hijmans, J. C., and Shearin, D. B. (1965). Partial deletion of short arms of chromosome No. 5. Report of a case in a fraternal twin. Amer. F. Dis. Child., 109, 85.

Hirschhorn, K., Cooper, H. L., and Firschein, I. L. (1965). Deletion of short arms of chromosome 4-5 in a child with defects of midline fusion. Humangenetik, 1, 479.

Holman, G. H., Erkman, B., Zacharias, D. L., and Koch, H. F. (1963). The 18-trisomy syndrome: two new clinical variants. One with associated tracheo-oesophageal fistula and the other with probable occurrence. New Engl. F. Med., 268, 982.

Hook, E. B., Lehrke, R., Roesner, A., and Yunis, J. J. (1965). Trisomy-18 in a 15 -year-old female. Lancet, 2,910 .

-, and Yunis, J. J. (1965). Trisomy-18 syndrome with normal karyotype. F. Amer. med. Ass., 193, 840.

Huehns, E. R., Hecht, F., Keil, J. V., and Motulsky, A. G. (1964). Developmental hemoglobin anomalies in a chromosomal triplication: D1 trisomy syndrome. Proc. nat. Acad. Sci. (Wash.), 51, 89.

Hustinx, T. W. J., Ruys, P. J. A., Stoelinga, G. B. A., and Wijffels, J. C. H. M. (1964). Het syndroom met drie chromosomen 17-18 (17-18 of $\mathrm{E}_{1}$ trisomie). Maandschr. Kindergeneesk., 32, 655.

Jacobs, P. A., Brunton, M., Court Brown, W. M., Doll, R., and Goldstein, H. (1963). Change of human chromosome count distributions with age: evidence for a sex difference. Nature (Lond.), 197, 1080.

Koenig, E. U., Lubs, H. A., and Brandt, I. K. (1962). The relationship between congenital anomalies and autosomal chromosome abnormalities. Yale f. Biol. Med., 35, 189.

Lafourcade, J., Bocquet, L., Cruveilier, J., Saraux, H., Berger, R., Lejeune, J., Heuet de Barochez, Y., and Turpin, R. (1964). Aberrations chromosomiques et malaidies humaines. Un contribution à l'étude anatomique de la trisomie -13. Bull. Soc. Méd. Hôp. (Paris), 115, 383.

Lejeune, J., Delthil, P., and Berger, R. (1963). A case of 17trisomy. Arch. franç. Pédiat., 20, 737.

- Turpin, R., and Gautier, M. (1959). Le mongolisme. Premier exemple d'aberration autosomique humaine. Ann. Génét., I, 2, 41.

Levkoff, A. H., Mather, G. B., and Eisenstein, R. P. (1964). A case of trisomy 16-18 syndrome. Speculation on pathogenesis of chromosome-induced malformations. Amer. F. Dis. Child., 107, 300.

Lewis, A. J. (1964). The pathology of 18-trisomy. F. Pediat., 65, 92.

Lewis, F. W. J., and Faint, S. (1965). Trisomies of D13-15 and E17-18: two cases. Hum. Chromos. Newsl., No. 15, p. 12.

, and Haas, L. (1965). Group E trisomy in a triple X female infant. ibid., No. 16, p. 21.

Lubs, H. A., Jr., Koenig, E. U., and Brandt, I. K. (1961). Trisomy 13-15: a clinical syndrome. Lancet, 2, 1001.

McKusick, V. A. (1961). Medical genetics 1960. f. chron. Dis., $14,38$.

Marden, P. M., Smith, D. W., and McDonald, M. J. (1964). Congenital anomalies in the newborn infant, including minor variations. A study of 4,412 babies by surface examination for anomalies and buccal smear for sex chromatin. F. Pediat., 64, 357.

Marin-Padilla, M., Hoefnagel, D., and Benirschke, K. (1964). Anatomic and histopathologic study of two cases of D1 (13-15) trisomy. Cytogenetics, 3, 258.

Marshall, R., Newnham, R. E., Rawstron, J. R., Ellis, J. R., and Stevens, L. J. (1964). Features of 13-15 trisomy syndrome with normal karyotype. Lancet, $1,556$.

Méhes, K., and Bata, G. (1965). Congenital thrombocytopenia in 13-15 trisomy. ibid., 1, 1279.

Mikelsaar, A.-V. N. (1967). The mosaicity with respect to the deletion of a part of the long arm of one of the chromosomes of group D (in man). Genetica, 142.

Miller, J. Q., Picard, E. H., Alkan, M. K., and Gerald, P. S. (1962). Neurologic manifestations of 13-15 trisomy: a chromosome abnormality in arhinencephaly. Trans. Amer. neurol. Ass., 87, 51.

$\longrightarrow, \frac{}{,}$, Alkan, M. K., Warner, S., and Gerald, P. S. (1963). A specific congenital brain defect (arhinencephaly) in 13-15 trisomy.
New Engl. . Med., 268, 120 .

Miller, M., Robbins, J., Fishman, R., Medenis, R., and Rosenthal, I. (1963). A chromosomal anomaly with multiple ocular defects, including retinal dysplasia. Amer. F. Ophthal., 55, 901.

Miller, O. J., Breg, W. R., Warburton, D., Miller, D. A., deCapoa, A., and Chutorian, A. M. (1966). Deleted late-replicating
chromosome 4/5. Lancet, 2, 105.
Nakagome, Y., Komiya, K., and Arima, M. (1963). A case of trisomy 18 syndrome. Pediat. Univ. Tokyo, No. 8, p. 49.

Naujoks, H., and Carrasco, E. D. (1964). Missbildungen beim Nengeboren und trisomie 17-18. Gynaecologia (Basel), 157, 329.

Neimann, N., Pierson, M., Gilgenkrantz, S., Olive, D., and Kahn, C1. (1964). La trisomie 13-15. Arch. frans. Pédiat., 21, 661. Nigro, N., Franceschini, P., and Volante, G. (1964). La sindrome malformativa da trisomia del cromosoma 18. Minerva pediat., 16, 471.

Noades, J., Gavin, J., Tippett, P., Sanger, R., and Race, R. R. (1966). The X-linked blood group system Xg. Tests on British, $\frac{\mathscr{T}}{J}$ Northern American, and Northern European unrelated people and families. F. med. Genet., 3, 162.

Northcutt, R. C. (1962). Multiple congenital anomalies in a Negro के infant with 13-15 trisomy. Sth. med. F. (Bgham, Ala.), 55, 385.

Patau, K., Smith, D. W., Therman, E., Inhorn, S. L., and Wagner, $\vec{O}$ H. P. (1960). Multiple congenital anomaly caused by an extra autosome. Lancet, 1, 790.

, Thermann, E., Smith, D. W., and deMars, R. I. (1961). Trisomy for chromosome no. 18 in man. Chromosoma (Berl.), 12, 280.

Penrose, L. S. (1966). Dermatoglyphic patterns in large acrocentric trisomy. f. ment. Defic. Res., 10, $1,1$.

Pergament, E., and Kadotani, T. (1965). A new double aneuploid: XXY D-trisomy. Lancet, 2, 695.

Pfeiffer, R. A. (1964). Chromosome abnormalities in children with congenital malformations. Hum. Chromos. Newsl., No. 12, p. 10.

Powars, D., Rohde, R., and Graves, D. (1964). Foetal haemoglobin and neutrophil anomaly in the $\mathrm{D}_{1}$-trisomy syndrome. Lancet, 1 , 1363.

Prader, A. (1962). Die klinik der hänfigsten chromosomalen Störungen. Helv. med. Acta, 29, 403.

Registrar General (1966). Quarterly Return for England and Wales.

Ricci, N., and Borgatti, L. (1963). XXX 18-trisomy. Lancet, 2 1276.

-, Dallapiccola, B., Ventimiglia, B., Borgatti, L., Osti, L., and Alberti, R. (1966). Sulla trisomia 17-18. (Studio clinico ed anatomo patologico di 4 casi). Riv. patol. clin. sper., 7, 323.

Richards, B. W. (1967). Mongolism: The effects of trends in age a childbirth on incidence and chromosomal type. 7. ment. Sub norm., 13, 3.

Rohde, R. A., Hodgman, J. E., and Cleland, R. S. (1964). Multiple congenital anomalies in the $\mathrm{E}_{1}$-trisomy (group 16-18) syndrome. Pediatrics, 33, 258.

- Lee, A., and Sapin, S. (1963). A new trisomy-translocation chromosome (long-arm E/E). Lancet, 2, 1309.

Rosenfeld, R. L., Breibart, S., Isaacs, H., Klevit, H. D., and Mellman, W. J. (1962). Trisomy of chromosomes 13-15 and 17-18 in association with infantile arteriosclerosis. Amer. f. med. Sci., 244, 763.

Saraux, H., Lafourcade, J., Lejeune, J., Dhermy, P., Cruveillier, J., and Turpin, R. (1964). La trisomie 13 et son expression ophtalmologique. Arch. Ophtal. (Paris), 24, 581.

Schade, H., Schoeller, L., and Schultze, K. W. (1962). D-trisomy (Patau) syndrome with congenital myeloid leukemia. Med. Welt (Berl.), No. 50, p. 2690.

Schärer, K., Hauschtek, E., and Münlethaler, J. P. (1962). Trisomie syndrom D. Helv. med. Acta, 29, 423.

Scherz, R. G. (1966). Pathologic variations of the 17-18 trisomy. Med. Ann. D.C., 35, 195.

Seki, M., and Strauss, L. (1964). Absence of one umbilical artery. Analysis of 60 cases with emphasis on associated developmental aberrations. Arch. Path., 78, 446.

Sergovich, F., Madronich, J. S., Barr, M. L., Carr, D. H., and Langadon, W. A. (1963). The D-trisomy-syndrome: a casereport with description of ocular pathology. Canad. med. Ass. F., 89, 151.

Sidbury, J. B., Jr., Schmickel, R. D., and Gray, M. (1964). Findings in a patient with apparent deletion of short arms on one of the B group chromosomes. Society for Pediat. Res. 34th Ann.

Meetng. Seattle, June 18-20, 1964 (Abstract). F. Pediat., 65, 1098.

Singh, R. P., and Carr, D. H. (1967). Anatomic findings in human abortions of known chromosomal constitution. Obstet. and Gynec., 29, 806.

Smith, D. W. (1964). Autosomal abnormalities. Amer. F. Obstet. Gynec., 90, 1055.

-, Patau, K., Therman, E., and Inhorn, S. L. (1960). A new autosomal trisomy syndrome: multiple congenital anomalies caused by an extra chromosome. F. Pediat., 57, 338. 
$-,-\longrightarrow,-$ and - (1962). The no. 18 trisomy syndrome. ibid., 60, 513. syndrome. ibid., 62, 326 .

Snodgrass, G. J. A. I., Butler, L. J., France, N. E., Crome, L., and Russell, A. (1966). The ' $D$ ' (13-15) trisomy syndrome: an analysis of 7 examples. Arch. Dis. Childh., 41, 250.

Steinberg, J. B., and Jackson, J. F. (1963). The 16-18 trisomy syndrome. Amer. F. Dis. Child., 105, 213.

Stewart, L. B., and Bowles, A. P. (1963). The genetic defect, no. 18 trisomy. F. nat. med. Ass. (N.Y.), 42, 520.

Stoller, A., and Collman, R. D. (1965). Virus aetiology for Down's syndrome (mongolism). Nature (Lond.), 208, 903.

Szotowa, W., and Kowalewska, B. (1965). Trisomy-E-like syndrome. Lancet, 2, 696.

Szulman, A. E. (1965). Chromosomal aberrations in spontaneous human abortions. New Engl. F. Med., 272, 811.

Taylor, A. I., and Moores, E. C. (1967). A sex chromatin survey of newborn children in two London hospitals. f. med. Genet., 4, 258.

-, and Polani, P. E. (1964). Autosomal trisomy syndromes, excluding Down's. Guy's Hosp. Rep., 113, 231.

Therman, E., Patau, K., de Mars, R. I., Smith, D. W., and Inhorn, S. L. (1963). Iso/telo- $D_{1}$ mosaicism in a child with an incomplete $\mathrm{D}_{1}$ trisomy syndrome. Port. Acta biol. A, 7, 211.

- - Smith, D. W., and DeMars, R. I. (1961). The Dtrisomy and XO gonadal dysgenesis in two sisters. Amer. F. hum. Genet., 13, 193.

Thiede, H. A., and Salm, S. B. (1964). Chromosome studies of human spontaneous abortions. Amer. F. Obstet. Gynec., 90, 205.

Tolksdorf, M., Hansen, H. G., Sinatsbachsch, H., Lehmann, W., Nitsch, N., and Wiedemann, H. R. (1963). Missbildungssyndrom mit Trisomie der Gruppe 16-18. Klin. W schr., 41, 354.

Tönz, O., Tobler, R., Joss, E., Bergemann, E., and Gloor, R. D. (1965). Trisomie-18-Syndrom. Mitteilung von drei Fällen. Schweiz. med. Wschr., 95, 509.

Townes, P. L., DeHart, G. K., Hecht, F., and Manning, J. A. (1962a). Trisomy $13-15$ in a male infant. F. Pediat., 60, 528.

, Manning, J. A., and DeHart, G. K. (1962b). Trisomy-18 (16-18) associated with congenital glaucoma and optic atrophy. f. Pediat., 61, 755.

Trowell, H. R., and Hilton, H. B. (1963). A case of trisomy-18 syndrome. Hum. Chromos. Newsl., No. 10, p. 15.
Turner, B., Dulk, G. M. den, and Watkins, G. (1964). The 17-18 trisomy and 21 trisomy syndromes in siblings. F. Pediat., 64, 601 .

Uchida, I. A., Bowman, J. M., and Wang, H. C. (1962a). The 18trisomy syndrome. New Engl. F. Med., 266, 1198.

-, Lewis, A. J., Bowman, J. M., and Wang, H. C. (1962b). A case of double trisomy: trisomy no. 18 and triplo-X. $\mathcal{f}$. Pediat., 60, 498.

Van Wijck, J. A. M., Stolte, L. A. M., Van Kessel, H. I. A. M., and Tijdink, G. A. J. (1961). A trisomic child of a hyperthyroid mother. Lancet, $1,887$.

Voorhess, M. L., Aspillaga, M. J., and Gardner, L. I. (1964). Trisomy-18 syndrome with absent radius, varus deformity of a hand and rudimentary thumb. $\mathcal{F}$. Pediat., 65, 130.

Wagshal-Ives, R., and Berman, J. L. (1963). 17-18 trisomy syndrome. Hum. Chromos. Newsl., No. 11, p. 12.

Warburg, M., and Mikkelsen, M. (1963). A case of 13-15 trisomy or Bartholin-Patau's syndrome. Acta ophthal. (Kbh.), 41, 321.

Warkany, J., Weinstein, E. D., Soukup, S. W., Rubinstein, J. H., and Curless, M. C. (1964). Chromosome analyses in a children's hospital: selection of patients and results of studies. Pediatrics, 33, 290 and 454.

Weber, W. W., Mamunes, P., Day, R., and Miller, P. (1964). Trisomy 17-18 (E): studies in long-term survival with report of two autopsied cases. ibid., 34, 533.

Weichsel, M. E., and Luzzatti, L. (1965). Trisomy 17-18 syndrome with congenital extrahepatic biliary atresia and congenital amputation of the left foot. F. Pediat., 67, 324.

Weiss, L., DiGeorge, A. M., and Baird, H. W. (1962). Four infants with the trisomy-18 syndrome and one with trisomy-18 mosaicism. Trans. Soc. Pediat. Res. 32nd Annual Meeting, May 8-10, 1962 (Abstract). Amer. F. Dis. Child., 104, 533.

Windmiller, J., Marks, J. F., Reimold, E. W., Costales, F., and Peake, C. (1965). Trisomy-18 with biliary atresia. Report of a case. F. Pediat., 67, 327.

Wolf, U., Reinwein, R., Porsch, R., Schröter, R., and Baitsch, H. (1965). Defizienz an den kurzen Armen eines Chromosoms Nr. 4. Humangenetik., 1, 397.

Yunis, J. J., Hook, E. B., and Mayer, M. (1964). Deoxyribosenucleic-acid replication pattern of trisomy 18. Lancet, 2, 286.

Zellweger, H., Beck, K., and Hawtrey, C. E. (1964). Trisomy-18. Report of a case and discussion of the syndrome. Arch. intern. Med., 113, 598.

\section{Appendix}

This appendix consists of 54 individual case reports and a table of birth and survival data in the 54 subjects (Table $A$ ). The subjects are identified by initials, date of birth, and unit number as recommended by the Chicago Conference (1966). For the sake of brevity, birth and survival data, summarized in Table A, are not repeated in the individual case histories. Cytogenetic findings are reported as in the Chicago nomenclature. Full blood group analysis and analysis of G6PD, haptoglobins, haemoglobins, transferrins, and serum $\mathrm{Xm}$ and Gc groups were undertaken on the majority of subjects and their parents. Most of the data are non-contributory and are referred to only if they are of interest.

\section{Edwards' Syndrome}

\section{HD 291065/2976 우}

Pregnancy followed three years of infertility. No family history of congenital malformations. Clinical features: dolicocephaly, wide-set eyes, corneal opacities, low-set malformed ears, micrognathia, high-arched palate. Short neck with excess nape skin. Narrow shoulders, shield chest, short sternum. Flexion deformity of fingers with overriding index finger. Hypoplastic finger-nails. Rocker-bottom feet. Short wide dorsiflexed halluces. Syndactyly of second and third toes. Limited hip abduction. Enlarged clitoris and labia. Generally-hypertonia, seizures, and ? ventricular septal defect. Fed poorly, failed to thrive. Died at 61 days. No necropsy. Dermatoglyphs: 5 simple arches, 5 dysplastic digits; palmar ridge dysplasia; bilateral simian creases. Chromatin positive. Chromosomes: $47, \mathrm{XX}, 18+$.

\section{EF $111265 / 3002$ ㅇ}

Condition at birth, poor. Apgar scores 4, 5, 7, and 8 at $1,2,3$, and 4 minutes. Clinical features: low-set normal ears, micrognathia. Short webbed neck. Rocker-bottom feet. Normal heart sounds. Died at 11 days. No necropsy. No dermatoglyphic studies. Chromosomes: $47, \mathrm{XX}, \mathrm{Dp}-\mathrm{mat}, 18+$. Dp - also present in mother and maternal grandmother. 
TABLE A

BIRTH AND SURVIVAL DATA IN THE PRESENT SERIES

\begin{tabular}{|c|c|c|c|c|c|c|c|c|c|c|c|c|c|c|c|c|c|}
\hline & & 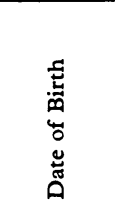 & 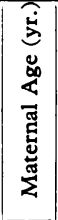 & 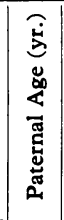 & 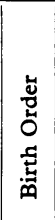 & 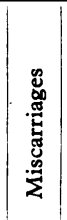 & 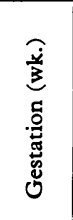 & 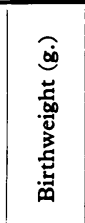 & 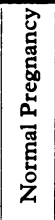 & 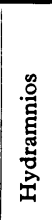 & 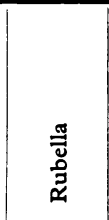 & 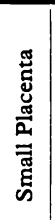 & 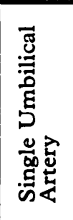 & 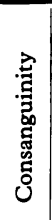 & 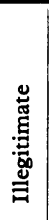 & $\stackrel{ð}{\mathscr{ٌ}}$ & 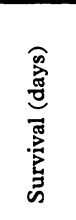 \\
\hline $\begin{array}{l}\text { HD } \\
\text { EF } \\
\text { EH } \\
\text { KJ } \\
\text { RL } \\
\text { PS } \\
\text { ES } \\
\text { CW } \\
\text { TW } \\
\text { SA } \\
\text { BC } \\
\text { AT } \\
\text { SM } \\
\text { BC } \\
\text { CO } \\
\text { CG } \\
\text { TS } \\
\text { DC } \\
\text { MK } \\
\text { JV } \\
\text { BP } \\
\text { ML } \\
\text { BW } \\
\text { SW } \\
\text { AW } \\
\text { SC }\end{array}$ & 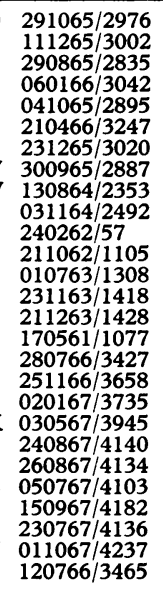 & $\begin{array}{r}29.10 .65 \\
11.12 .65 \\
29.8 .65 \\
6.1 .66 \\
4.10 .65 \\
21.4 .65 \\
23.12 .65 \\
30.9 .65 \\
13.8 .64 \\
3.11 .64 \\
24.2 .64 \\
21.10 .62 \\
1.7 .62 \\
23.11 .63 \\
21.12 .63 \\
17.63 \\
28.5 .61 \\
25.17 .66 \\
2.11 .66 \\
3.1 .67 \\
24.67 \\
26.8 .67 \\
5.8 .67 \\
15.7 .67 \\
23.9 .67 \\
1.10 .67 \\
12.7 .67 \\
\end{array}$ & $\begin{array}{l}28 \\
25 \\
28 \\
22 \\
43 \\
25 \\
20 \\
33 \\
27 \\
33 \\
21 \\
19 \\
32 \\
42 \\
30 \\
27 \\
27 \\
25 \\
34 \\
23 \\
37 \\
27 \\
40 \\
19 \\
42 \\
29 \\
35\end{array}$ & $\begin{array}{l}32 \\
28 \\
28 \\
30 \\
O \\
33 \\
33 \\
38 \\
31 \\
34 \\
O \\
0 \\
32 \\
41 \\
34 \\
34 \\
32 \\
27 \\
40 \\
23 \\
40+ \\
39 \\
44 \\
27 \\
53 \\
30 \\
34\end{array}$ & \begin{tabular}{r|}
2 \\
2 \\
4 \\
2 \\
3 \\
2 \\
1 \\
4 \\
2 \\
2 \\
1 \\
1 \\
0 \\
10 \\
3 \\
2 \\
2 \\
2 \\
4 \\
2 \\
6 \\
4 \\
4 \\
1 \\
1 \\
3 \\
3
\end{tabular} & 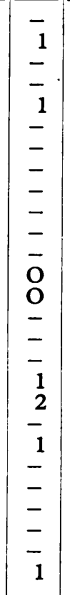 & $\begin{array}{l}40 \\
41 \frac{1}{2} \\
0 \\
40 \\
43 \\
40 \\
42 \\
44 \\
43 \\
45 \\
43 \\
42 \\
0 \\
44 \\
42 \\
40 \\
42 \\
42 \\
40 \\
39 \\
42 \\
40 \\
41 \\
37\end{array}$ & \begin{tabular}{|l|}
1822 \\
2094 \\
0 \\
2122 \\
2802 \\
2492 \\
2094 \\
1954 \\
1938 \\
2464 \\
1953 \\
2010 \\
2350 \\
2491 \\
1812 \\
1812 \\
2136 \\
2998 \\
2380 \\
2774 \\
2206 \\
1842 \\
1612 \\
2178 \\
2380 \\
2125 \\
2548
\end{tabular} & $\begin{array}{l}+ \\
+ \\
+ \\
+ \\
+ \\
0 \\
+ \\
+ \\
+ \\
+ \\
+ \\
+ \\
+ \\
+ \\
+ \\
+ \\
+ \\
+ \\
+ \\
+ \\
+ \\
+ \\
+\end{array}$ & 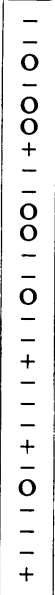 & $\begin{array}{c}\overline{-} \\
\mathrm{o} \\
\mathrm{O} \\
\mathrm{O} \\
\overline{-} \\
\overline{-} \\
\mathrm{o} \\
+(4 / 52) \\
\overline{\mathrm{o}} \\
\overline{-} \\
\overline{-} \\
\overline{-} \\
\overline{-} \\
\overline{\mathbf{o}} \\
\overline{-} \\
\overline{-} \\
-\end{array}$ & $\begin{array}{l}0 \\
+ \\
0 \\
+ \\
0 \\
0 \\
+ \\
+ \\
- \\
0 \\
0 \\
0 \\
0 \\
0 \\
\frac{0}{0} \\
0 \\
0 \\
- \\
\\
0 \\
0 \\
- \\
+ \\
-\end{array}$ & $\begin{array}{l}\mathrm{O} \\
\mathrm{O} \\
\mathrm{O} \\
\mathrm{O} \\
\mathrm{O} \\
+ \\
\mathrm{O} \\
\mathrm{O} \\
\mathrm{O} \\
\mathrm{O} \\
\mathrm{O} \\
+ \\
\mathrm{O} \\
\overline{\mathrm{o}} \\
\mathrm{O} \\
- \\
- \\
\overline{\mathrm{O}} \\
\mathrm{O} \\
\mathrm{O} \\
\mathrm{O} \\
\mathrm{O} \\
\mathrm{O} \\
\mathrm{O}\end{array}$ & $\begin{array}{l}\overline{-} \\
\overline{-} \\
\bar{z} \\
= \\
= \\
= \\
= \\
= \\
= \\
= \\
= \\
= \\
= \\
= \\
= \\
= \\
=\end{array}$ & $\begin{array}{l}= \\
= \\
= \\
= \\
= \\
= \\
= \\
= \\
\pm \\
= \\
= \\
= \\
= \\
= \\
= \\
= \\
\pm \\
\pm \\
\pm \\
=\end{array}$ & $\begin{array}{l}\mathrm{F} \\
\mathrm{F} \\
\mathrm{F} \\
\mathrm{F} \\
\mathrm{M} \\
\mathrm{M} \\
\mathrm{F} \\
\mathrm{F} \\
\mathrm{F} \\
\mathrm{F} \\
\mathrm{F} \\
\mathrm{F} \\
\mathrm{F} \\
\mathrm{F} \\
\mathrm{F} \\
\mathrm{F} \\
\mathrm{F} \\
\mathrm{M} \\
\mathrm{M} \\
\mathrm{F} \\
\mathrm{M} \\
\mathrm{F} \\
\mathrm{F} \\
\mathrm{F} \\
\mathrm{F}\end{array}$ & \begin{tabular}{|r}
61 \\
11 \\
33 \\
12 \\
4 \\
1 \\
35 \\
1 \\
103 \\
59 \\
11 \\
60 \\
30 \\
5 \\
42 \\
1670 \\
207 \\
89 \\
99 \\
18 \\
10 \\
Alive \\
120 \\
50 \\
123 \\
Alive \\
93
\end{tabular} \\
\hline $\begin{array}{l}\text { SE } \\
\text { PF } \\
\text { LG } \\
\text { MJ } \\
\text { SM } \\
\text { HP } \\
\text { CW } \\
\text { MR } \\
\text { SC } \\
\text { JM } \\
\text { MR } \\
\text { VP } \\
\text { MF } \\
\text { JC } \\
\text { MF } \\
\text { KA } \\
\text { PA } \\
\text { TP } \\
\text { PM } \\
\text { JN } \\
\text { BS } \\
\text { VN } \\
\text { LB } \\
\text { DW } \\
\text { GH }\end{array}$ & 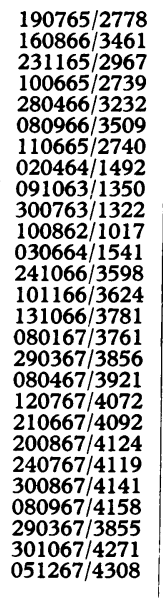 & 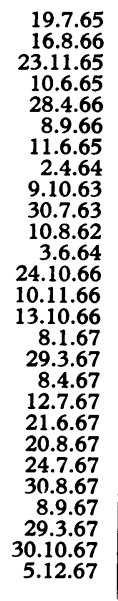 & $\begin{array}{l}40 \\
42 \\
18 \\
30 \\
31 \\
21 \\
42 \\
21 \\
35 \\
27 \\
39 \\
25 \\
30 \\
45 \\
33 \\
24 \\
43 \\
28 \\
36 \\
29 \\
28 \\
27 \\
37 \\
27 \\
24 \\
31 \\
27\end{array}$ & $\begin{array}{l}O \\
32 \\
23 \\
0 \\
32 \\
23 \\
59 \\
20 \\
30 \\
33 \\
40 \\
23 \\
33 \\
46 \\
34 \\
27 \\
43 \\
29 \\
42 \\
O \\
26 \\
26 \\
O \\
34 \\
32 \\
31 \\
O\end{array}$ & $\begin{array}{l}5 \\
4 \\
1 \\
5 \\
3 \\
1 \\
4 \\
1 \\
0 \\
2 \\
0 \\
3 \\
4 \\
3 \\
2 \\
2 \\
2 \\
3 \\
7 \\
2 \\
2 \\
4 \\
1 \\
2 \\
2\end{array}$ & 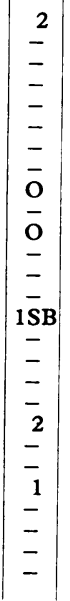 & $\begin{array}{l}37 \\
36 \\
38 \frac{1}{2} \\
43 \\
40 \\
40 \\
37 \\
34 \mathrm{I} \\
39 \\
38 \\
\mathrm{O} \\
32 \\
42 \\
38 \\
40 \\
40 \\
37 \\
40 \\
38 \mathrm{C} \\
40 \\
40 \\
38 \mathrm{C} \\
40 \\
30 \\
40 \\
40\end{array}$ & $\begin{array}{l}2746 \\
2440 \\
O \\
2802 \\
2942 \\
2884 \\
2942 \\
1502 \\
2151 \\
1471 \\
O \\
1400 \\
3655 \\
2436 \\
2576 \\
2150 \\
1842 \\
3110 \\
2802 \\
2444 \\
3217 \\
2912 \\
1696 \\
3175 \\
1464 \\
3182 \\
2746\end{array}$ & $\begin{array}{l}+ \\
+ \\
+ \\
+ \\
+ \\
+ \\
+ \\
- \\
0 \\
0 \\
0 \\
+ \\
+ \\
+ \\
+ \\
0 \\
+ \\
+ \\
+ \\
0 \\
+ \\
+ \\
0 \\
+ \\
+ \\
+\end{array}$ & $\begin{array}{l}\overline{-} \\
\overline{-} \\
0 \\
\frac{-}{-} \\
\overline{0} \\
\overline{0} \\
+ \\
\overline{-} \\
\overline{0} \\
\mathrm{O} \\
\mathrm{O} \\
\frac{\mathrm{O}}{\mathrm{o}} \\
\overline{0} \\
\overline{0} \\
-\end{array}$ & 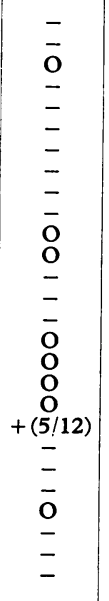 & $\begin{array}{l}0 \\
+ \\
0 \\
0 \\
+ \\
0 \\
+ \\
0 \\
0 \\
0 \\
0 \\
+ \\
\\
\overline{0} \\
0 \\
0 \\
0 \\
0 \\
0 \\
+ \\
0 \\
- \\
0 \\
-\end{array}$ & $\begin{array}{l}\mathrm{O} \\
\mathrm{O} \\
\mathrm{O} \\
+ \\
+ \\
\mathrm{O} \\
\mathrm{O} \\
\mathrm{O} \\
+ \\
\\
\mathrm{o} \\
\overline{-} \\
\mathrm{O} \\
\mathrm{O} \\
\mathrm{O} \\
\mathrm{O} \\
\mathrm{O} \\
\mathrm{O} \\
\overline{\mathrm{O}} \\
\overline{\mathrm{O}} \\
\underline{-}\end{array}$ & 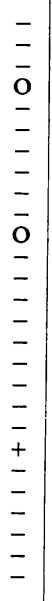 & $\begin{array}{l}z \\
z \\
\pm \\
z \\
z \\
z \\
z \\
\bar{o} \\
z \\
z \\
z \\
z \\
z \\
z \\
z \\
z \\
\pm \\
z \\
z \\
z\end{array}$ & $\begin{array}{l}F \\
M \\
F \\
F \\
F \\
M \\
M \\
M \\
F \\
M \\
M \\
M \\
M \\
M \\
F \\
M \\
F \\
F \\
F \\
F \\
M \\
F \\
M \\
M \\
F \\
F \\
M \\
M \\
F\end{array}$ & $\begin{array}{r}26 \\
9 \\
6 \\
6 \\
14 \\
6 \\
3 \\
135 \\
<1 \\
1 \\
30 \\
19 \\
1 \\
26 \\
21 \\
<1 \\
67 \\
64 \\
168 \\
61 \\
88 \\
17 \\
60 \\
2 \\
62 \\
1 \\
33 \\
\text { Alive }\end{array}$ \\
\hline
\end{tabular}

+ Feature present; - feature absent; O not known; I induction of labour; C caesarean section; SB stillbirth.

\section{EH 290865/2835 우}

Pregnancy normal, spontaneous breech delivery. Flaccid and cyanosed at birth. Clinical features: microcephaly (head circumference $28 \mathrm{~cm}$.), bilateral microphthalmos, micrognathia. Umbilical hernia. Both hands, 6 digits. Small lower lumbar meningocele (repaired satisfactorily). Generally-hypotonia, retarded, failed to thrive. Died at 33 days. Necropsy: heart normal. Enlarged right lobe of liver. Small accessory spleen. Horseshoe kidney. Brain hydrocephalic. No $47, \mathrm{XX}, 18+$.

\section{KJ 060166/3042 웅}

Placenta small (325 g.). Clinical features: Elongatea skull, wide-set eyes, low-set malformed ears, micrognathia. Neck short, not webbed. Flexion deformity of fingers, long hyperconvex finger-nails. Feet normal except for short dorsiflexed big toes. Sternum short, chest shield-shaped. Neurologically-generalized hy$\frac{C^{\circ}}{\mathscr{C}}$ $\stackrel{\mathscr{\infty}}{\rightarrow}$ 
pertonia, jitteriness, apnoeic attacks, one seizure. Genitalia -enlarged phallus, swollen labia. Fed poorly, became jaundiced, died at 12 days. Necropsy (S. J. Surtees): diaphragm abnormally thin, especially on left. Heart enlarged, with large ventricular septal defect, significant degree of atrial septal defect. Ductus arteriosus widely patent. Meckel's diverticulum. Other systems, including CNS, normal. $55 \%$ foetal $\mathrm{Hb}$. Dermatoglyphs: 1 loop, 6 simple arches, 3 dysplastic digits; palms, soles dysplastic. Chromatin positive. Chromosomes: $47, \mathrm{XX}, 18+$.

\section{RL 041065/2895 ð (Fig. 2a)}

Apgar score 4 at birth. Clinical features: elongated skull, wide-set small eyes, epicanthic folds, low-set malformed ears, micrognathia. Short webbed neck. Mild flexion deformity of fingers, rudimentary thumbs (short and distally implanted). Calcaneo-valgus feet, marked syndactyly of second and third toes, short dorsiflexed halluces (Fig. 2h). Hypoplastic toe-nails. Short sternum. Testes undescended, penis very small. Neurologically-mild hypertonia, right-sided facial palsy (Fig. 2a). Responded to painful stimuli. Apnoeic attacks. Vomited after feeds; tracheo-oesophageal fistula suspected but ruled out by barium swallow. Chest $x$-ray, gross cardiomegaly. ECG normal. Died at 4 days. Necropsy (Robelle): heart enlarged, otherwise normal. Left kidney large and distorted with double ureters. Right kidney absent. Other systems normal. Dermatoglyphs: 10 simple arches on fingertips, normally situated $t$ triradii; bilateral simian creases. Chromatin positive male. Chromosomes (blood and skin): $48, \mathrm{XXY}, 18+$.

\section{PS 210466/3247 के}

Clinical features: elongated skull, wide-set eyes with epicanthic folds, low-set malformed ears, partial hare-lip, micrognathia. Capillary haemangioma on forehead. Flexion deformity of fingers, retroflexible thumbs. Equino-varus feet, short dorsiflexed big toes, partial syndactyly of second and third toes. Short sternum. Flexion deformity of left wrist. Exomphalos, bilateral undescended testes. Congenital heart disease suspected. Apnoeic attacks, died at 1 day. No necropsy. Dermatoglyphs: simple arches on at least 3 digits, $t$ triradius normally situated; simian crease on left hand. Chromosomes: $47, \mathrm{XY}, 18+$.

\section{ES 231265/3020우}

Clinical features: elongated skull (head circumference $33 \mathrm{~cm}$.), wide-set eyes with epicanthic folds, large primitive low-set ears, extreme micrognathia. Palate high and arched, mouth small. Neck short, excess nape skin. Flexion deformity of fingers, retroflexible distally implanted thumbs. Calcaneo-valgus feet, hypoplastic toe-nails. Chest-shield shaped, short sternum, limited hip abduction. Slight umbilical hernia. Generally-hypertonia, jittery, opisthotonic posture. Respiratory distress soon after birth, recovered. Failed to thrive, died at 35 days. Necropsy: heart dextro- posed, ventricular septal defect. Diaphragm abnormally thin. Brain macroscopically normal. Sections showed slight ventricular dilatation. One eye sectioned, normal. $56 \%$ foetal Hb. Dermatoglyphs: simple arches on 7 digits; positions of palmar triradii not seen; bilateral single palmar creases. Chromatin positive. Chromosomes: 46 chromosomes, with a single chromosome 18 and a chromosome resembling a 12 (Fig. 1b), also a $\mathrm{D}$ chromosome with very large satellites; 46,XX,Ds + , 18-, ? $18 p+q+$. (Parents-normal chromosomes except baby's mother and maternal grandmother had marker D chromosome : $46, \mathrm{XX}, \mathrm{Ds}+$.)

\section{CW 300965/2887 우}

Clinical features: microcephaly, low-set malformed ears, webbed neck. Capillary haemangioma. Flexion deformity of fingers, partial syndactyly of right thumb. Thumbs retroflexible. Calcaneo-valgus feet, short dorsiflexed big toes, hypoplastic nails. Sternum short, chest shield-shaped, wide-spaced nipples. Congenital heart disease suspected. Died at 1 day. Necropsy $(H$. D. Cheetham): haemorrhages in lungs but aeration good. Heart-valvular foramen ovale, blood-filled cysts on mitral valve. Stomach-superficial ulcers on mucosa. Torsion at the mesentery, with infarction of most of small intestine. Brain congested, but macroscopically normal. Other systems normal. $74.5 \%$ foetal $\mathrm{Hb}$. Dermatoglyphs not possible. Chromosomes: $47, \mathrm{XX}, 18+$.

\section{TW 130864/2353우}

Assisted breech delivery. Condition at birth poor. Digitalized from 6th day. Clinical features: elongated skull, low-set ears, small skin bridge between upper and lower lids of right eye. Flexion deformity of fingers. Cyanosed, failed to thrive, died at 103 days. Necropsy: heart globular, enlarged, with two atria, single ventricle. Complete atresia of pulmonary valve. Other systems normal. More than 3 simple arches on fingertips. Chromosomes: $47, \mathrm{XX}, 18+$.

\section{SA $031164 / 2492$ 운 $\quad$ (Fig. 2i)}

One older and 2 younger sibs alive and well. No family history of congenital malformations or mental defect. Pregnancy complicated by maternal vomiting, oedema, and high blood pressure. Delivery normal, spontaneous, vertex presentation. Condition at birth good. Unable to suck, tube-fed. Clinical features: low-set malformed ears, micrognathia, antero-posterior elongation of skull, flexion deformity of fingers. Hip abduction limited. Feet abnormal; left equino-varus, right calcaneo-valgus deformities. Congenital heart disease 'probably ventricular septal defect', generalized hypertonia. Failed to thrive, died at 2 months. Complete necropsy not performed. Brain and right eye studied. Eye normal (N. Ashton). Brain-unduly thin corpus callosum, areas of dysplastic cerebellar tissue, failure of convolution formation of inferior olives (R. M. Norman). Dermatoglyphs: simple arches on all fingers, toes; palmar triradii normally situated; 2 palmar creases bilaterally. Chromosomes (blood and skin): modal 
number 48 with additional chromosomes in $\mathrm{C}$ and $\mathrm{E}$ groups. Oral smear-cells with two Barr bodies, autoradiography confirmed two late-labelling $\mathrm{Xs}$. $48, \mathrm{XXX}, 18+$.

\section{BC 240262/57 오}

Younger sister alive, well. Clinical features: hare-lip, cleft palate, spina bifida, meningocele, platybasia, dolicocephaly. Paralysis below spina bifida, presystolic gallop, postsystolic murmur. Died at 11 days. Necropsy: heart-Eisenmenger's complex, ventricular septal defect, dextroposition. CNS-localized leptomeningitis, internal hydrocephalus. No dermatoglyphs. Chromatin positive. Chromosomes (skin): 47, XX,18+. (Case previously published, Taylor and Polani, 1964, Case 1.)

\section{AT 211062/1105 우 (Fig. 2e)}

Spontaneous vertex delivery. Clinical features: anteroposterior elongation of skull, low-set ears, left pinna (Fig. 2e) very deformed. High-arched palate, micrognathia. Flexion deformity of fingers, with short, distally implanted retroflexible thumbs. Both radii shortened. Short dorsiflexed halluces. Congenital heart disease. Genitalia enlarged. Sternum short, thorax narrow. Generally-hypertonia, left 7th nerve palsy. Varying jaundice over first month. High-arched palate prevented normal sucking, failed to thrive, died at 60 days. Necropsy: heart, large interventricular septal defect, marked pulmonary stenosis; aorta dextroposed. Horseshoe kidney. Dermatoglyphs: 4 simple arches on fingertips, patterns on other digits not visible; normally situated $t$ triradii. Chromatin positive. Chromosomes: $47, \mathrm{XX}, 18+$. (Case previously published, Taylor and Polani, 1964, Case 2.)

\section{SM 010763/1308}

Clinical features: elongated skull, low-set malformed ears, micrognathia. Severe flexion deformity of fingers. Rocker-bottom feet, short dorsiflexed halluces. Sternum short, hip abduction limited. Hernia present. Sucked poorly, failed to thrive, died at 30 days. Necropsy: ventricular septal defect, patent ductus arteriosus. Horseshoe kidney. Heterotopic pancreatic tissue. Dermatoglyphs: 10 simple arches on fingertips; $t$ triradius in $t^{\prime}$ position, 2 palmar creases bilaterally. Chromatin positive. Chromosomes: 47,XX,18+. (Case previously published, Taylor and Polani, 1964, Case 3.)

\section{BC $231163 / 1418$ 우}

Clinical features: dolicocephaly, low-set ears, micrognathia, microstomia. Excess skin at nape, flexion deformity of fingers. Generally-hypertonia, suspected ventricular septal defect. Pneumonia, died at 5 days. Necropsy: right-sided congestion of heart, large subvalvular ventricular septal defect, widely patent foramen ovale. Lungs showed extensive bronchopneumonia. Other systems, nothing abnormal detected. CNS normal. Dermatoglyphs: 10 simple arches; ridges on palms not visible. Chromosomes: $47, \mathrm{XX}, 18+$.
(Case previously published, Taylor and Polani, 1964, Case 4.)

\section{CO $211263 / 1428$ 우}

Two of mother's sibs have had twins, no family his- $\overrightarrow{\bar{N}}$ tory of congenital malformations. Conditions at birthpoor, with generalized cyanosis. Clinical features: elongated skull, low-set ears, left ear malformed, slanting $\overline{\bar{c}}$ eyes, epicanthic folds, micrognathia. No neck webbing, $\underset{\top}{\vec{D}}$ no excess nape skin. Flexion deformity of fingers with $\mathrm{a}$ axial deviation. Distal digital creases poorly developed, absent on some digits. Thumbs rudimentary, with $\rightarrow$ appearance of thenar wasting. Partial syndactyly of all fingers. Calcaneo-valgus feet, short dorsiflexed big $\overrightarrow{\vec{\omega}}$ toes, partial syndactyly of 3 toes on right foot; 4 on left. Oे Finger-nails, toe-nails hypoplastic. Short sternum, $\overline{\overrightarrow{3}}$ shield-shaped chest. Abduction of hips limited. External genitalia abnormal, with enlarged phallus and ir labia. Cyanotic spells, heart murmur, generalized $\omega$ hypertonia. Failed to thrive, developed pneumonia, $N$ died at 6 weeks. Necropsy: interatrial, interventricular septal defects, patent ductus arteriosus, single umbilical artery. Small accessory spleen. Marked left hydroureter. Brain macroscopically and microscopically normal. Blood group studies (R. R. Race and R. Sanger) showed anomalous inheritance of $\mathrm{Xga}$ with propositus an $\mathrm{Xg}(\mathrm{a}-)$, daughter of an $\mathrm{Xg}(\mathrm{a}+)$ father, $\mathrm{Xg}(\mathrm{a}-)$ mother. Other blood groups confirm paternity. Propositus and father had $\mathrm{Hb} \mathrm{D}$ Punjab, an extremely rare finding in a purely Welsh family (H. Lehmann). Dermatoglyphs: simple arches, narrow radial loop; normally situated triradii; 2 palmar creares bilaterally. Chromatin posie tive. Chromosomes: $47, \mathrm{XX}, 18+$. (Case previously pub? lished, Taylor and Polani, 1964, Case 5.)

\section{CG $170561 / 1077$ 우}

No relevant family history. Condition at birth very poor. Pyloric stenosis with successful operation. Clinical features (20 months of age): dolicocephalic skull, microstomia, small low-set ears. High-arched palate with cleft in soft palate, left side of uvula. Neck short, not webbed. Short, distally implanted thumbs, left hand had 6 digits. Mild calcaneovalgus feet. Pelvis narrow, limited hip abduction. Short, Grade II mesocardial systolic murmur. Had a fit at about 6 months of age. Auditory testing revealed deafness. Obvious mental retardation. Developed bronchitis, died at 1670 days. No necropsy. Dermatoglyphs: 8 simple arches, no patterns visible on other digits ; $t$ triradius in $t^{\prime}$ position, 2 palmar creases bilaterally. Chromatin positive. Chromosomes (blood and skin): 3 modes, major cell line with 47 chromosomes (trisomy 18), minor cell line with 48 chromosomes (tetrasomy 18), and a line with 46 chromosomes (normal female): $46, \mathrm{XX} / 47, \mathrm{XX}$, $18+/ 48, \mathrm{XX}, 18+, 18+$.

\section{JT 280766/3427 우}

Pregnancy complicated by hydramnios. Apgar score 3 at birth. Clinical features: elongated skull, low-set malformed ears, micrognathia. Unilateral neck webb- 
ing. Severe flexion deformity of fingers with ulnar deviation, overriding index finger. Halluces broad, very short. Neurologically: generalized hypertonia, apnoeic attacks with convulsions. Bouts of jaundice. Gained weight slowly, frequent cyanotic attacks, very retarded. Died suddenly at 7 months. No necropsy. At 3 months (high) $20 \%$ foetal $\mathrm{Hb}$. Dermatoglyphs: 7 simple arches, 3 narrow loops; normally situated $t$ triradii. Chromosomes: $47, \mathrm{XX}, 18+$. (The father had a marker 18 chromosome: $46, \mathrm{XY}, 18 \mathrm{ps}$.)

\section{TS 251166/3658 우}

Paternal grandfather was a twin. Pregnancy complicated by threatened miscarriage at 2 months. Clinical features: antero-posterior elongation of skull, wide-set eyes, epicanthic folds. Pupils of both eyes eccentric, did not react to light. Low-set malformed ears, higharched palate, microstomia, micrognathia. Short neck with extra skin laterally (webbing) and behind. Flexion deformity of fingers, extremely hyperconvex finger-nails. Fifth finger left hand had missing phalanx. Thumbs distally implanted. Calcaneo-valgus feet, short dorsiflexed big toes. Abduction of hips and shoulders limited. Chest very wide, asymmetrical, right nipple about $1.3 \mathrm{~cm}$. below level of left nipple. Sternum had a bony prominence at end. Cyanosed after feeds, congenital heart disease suspected. Generalized hypotonia, retarded, failed to thrive, died at 89 days. Necropsy: ventricular septal defect, left atrium very small, underdeveloped. Brain superficially normal. $55.8 \%$ foetal Hb. Dermatoglyphs: 3 simple arches, 7 digits with ridge dysplasia; $t$ triradii in $t^{\prime}$ position bilaterally; simian crease on left hand. Chromatin positive. Chromosomes: 46,XX,18+. Unusually polymorphic No. 16 chromosomes present in baby's mother and maternal grandmother but not in proposita. A marker $\mathrm{D}$ chromosome $(\mathrm{Dp}-)$ present in baby's father and paternal grandmother but not in proposita.

\section{020167/3735 ðَ (Fig. 2c)}

Pregnancy uneventful, labour induced at 42 weeks. Normal delivery, vertex presentation. Apgar score 4 at birth. Clinical features: antero-posterior elongation of skull, microphthalmia, hypertelorism, epicanthic folds, normally placed malformed ears, micrognathia. Neck short with extra nape skin. Capillary haemangiomas on both eyclids. Flexion deformity of fingers with distal implantation of thumbs. Second, third, fourth toes webbed bilaterally. Halluces short, dorsiflexed, calcaneovalgus feet (Fig. 2g). Hip abduction limited. Testes undescended, umbilical hernia. Neurologically hypertonia, no auditory attention. Heart sounds normal, but cyanosis during feeds. Jaundiced, would not suckparesis of palate suspected. Failed to thrive, frequent apnoeic attacks, died at 9 days. Necropsy: atelectasis of right lung, retention cyst at upper pole of right kidney. Heart normal. Dermatoglyphs: 7 simple arches, 1 whorl, 1 ulnar loop; ridge dysplasia on right fifth digit and both palms; bilateral simian creases. Chromatin negative. Chromosomes: $47, \mathrm{XY}, 18+$.

\section{MK 030567/3945 đ}

No consanguinity. Paternal uncle of father had 2 or 3 sets of twins. No family history of congenital malformations. Mother worried at small amount of foetal movement during pregnancy. Delivery normal, vertex presentation. Condition at birth poor. Clinical features: elongated skull, wide-set eyes, bilateral microphthalmos, low-set malformed ears, micrognathia. Short webbed neck. Flexion deformity of fingers, distally implanted thumbs. Short dorsiflexed big toes, partial syndactyly of second and third digits, prominent heels, hypoplastic toe-nails. Shield-shaped chest, short sternum. Testes descended. Congenital heart disease, highpitched cry. Jittery, apnoeic spells, general hypotonia. Sucked poorly, jaundiced. Failed to thrive, died at 18 days. Necropsy (S. Wilson): ventricular septal defect, patent ductus arteriosus, coarctation of aorta, bicuspid aortic valve, right coronary artery absent. Diaphragm abnormally thin and deficient in muscle on left. Descending colon had mesentery. Other systems normal. Dermatoglyphs: 10 simple arches; distally placed $t$ triradius, simian creases bilaterally; no ridges on soles. Chromatin negative. Chromosomes: 47,XY,18+.

\section{JV 240867/4140 + (Fig. 2f)}

Sibs well. Pregnancy complicated by hydramnios. At birth, head circumference $33 \mathrm{~cm}$., length $46 \mathrm{~cm}$. Clinical features: bilateral microphthalmos, strabismus, normally set malformed ears, micrognathia. Neck short with excess nape skin. Left thumb distally implanted, retroflexible, rudimentary. Flexion deformity of fingers. Feet normal, but right heel prominent, nails hypoplastic. Chest shield-shaped, sternum short. Responded to auditory attention. Extreme hypotonia, jitteriness. Parasternal ? diastolic murmur. Minimal left-sided facial palsy. Haematoma on scalp. Genitalia enlarged, anus anteriorly displaced with a skin tag. Fed poorly, breathed with marked sternal recession. Died at 10 days. Necropsy: ventricular septal defect, defect in septum secundum, patent ductus arteriosus. Other systems normal. Brain had reduction in convolutions. $60 \%$ foetal $\mathrm{Hb}$. Dermatoglyphs: 7 simple arches, 2 radial loops; no pattern on rudimentary left thumb; distal $t$ triradius on right, no ridges on left palm. Chromatin positive. Chromosomes: $47, \mathrm{XX}, 18+$.

\section{BP 260867/4134 ð̛}

Three sibs well. Clinical features: elongated skull, wide-set small eyes, an epicanthic fold on right, low-set malformed ears, micrognathia. Short neck with excess nape skin. Flexion deformity of fingers, short, retroflexible thumbs. Short dorsiflexed halluces, calcaneovalgus feet. Hip abduction limited. Short sternum. Heart murmur, ?ventricular septal defect. Hypotonic, attacks of jaundice, failed to thrive, high-pitched cry. Alive at 3 months, making slow progress (still in hospital). $54 \%$ foetal Hb. Dermatoglyphs: 4 simple arches, 4 ulnar loops, 2 radial loops; normally situated $t$ triradii; no simian creases. Chromosomes: $47, \mathrm{XY}, 18+$. 


\section{050767/4103우}

Sibs well. No consanguinity or history of congenital malformations. Clinical features: odd-shaped skull, narrow laterally, elongated antero-posteriorly, with prominent occiput, marked hydrocephalus. Low-set malformed ears, micrognathia. Short, distally implanted thumbs, flexion deformity of fingers. Calcaneovalgus feet, short dorsiflexed halluces, hypoplastic toenails. Hip abduction tight. Congenital heart disease suspected. Spina bifida, sacral meningocele. Hypotonic, tendency to opisthotonic posture. No auditory attention. Fed with difficulty, weight gain poor. Meningocele repaired satisfactorily, but degree of hydrocephalus increased. Died at $\mathbf{4}$ months. Necropsy (I. M. Larkin): heart enlarged, globular, with small ventricular septal defect. Ductus closed. Brain, polymicrogyria, small degree of lateral ventricular dilatation. Dermatoglyphs: 10 simple arches, bilateral distal $t$ triradius; 2 palmar creases bilaterally. Chromosomes: $47, \mathrm{XX}, 18+$.

\section{BW 150967/4182 ㅇ (Fig. 2d)}

Clinical features: elongated skull (head circumference $32 \mathrm{~cm}$.). Wide-set eyes with possible corneal opacities, low-set malformed ears, high-arched palate, micrognathia, microstomia. Short neck with excess nape skin Flexion deformity of fingers, distally implanted thumbs. Prominent heels, short dorsiflexed big toes, hypoplastic toe-nails. Hip abduction limited. Hypertonic, congenital heart disease, high-pitched cry. Auditory attention positive. Died at 50 days. No necropsy. Dermatoglyphs: 10 simple arches, normally situated $t$ triradii; $C$ triradii missing on both palms; 2 creases bilaterally. Chromosomes: $47, \mathrm{XX}, 18+$.

\section{SW $230767 / 4136$ 우}

Two sets of twins in mother's family. Clinical features: elongated skull, wide-set eyes, strabismus, lowset malformed ears, high-arched palate, micrognathia. Rudimentary, retroflexible distally implanted thumb, flexion deformity of fingers on right. On left side, radial club hand with absent radius, short ulna, absent thumb. Hyperconvex finger-nails, hypoplastic toenails. Short sternum, shield-shaped chest. Congenital heart disease suspected. Hepatomegaly, purpuric rash. Hypotonia, jitteriness, apnoea, no auditory attention. Fed poorly, gained weight slowly, needed constant digitalization. Died at 123 days. Necropsy: report not yet available. Brain macroscopically normal. Dermatoglyphs: 9 simple arches on 9 digits; ridges present on palms, but no $t$ triradii; no simian creases. Chromosomes: 2 cell lines, normal female and 18 trisomic female: $46, \mathrm{XX} / 47, \mathrm{XX}, 18+$ with the 18 trisomic cell line the major one.

\section{AW $011067 / 4237$ 우}

Two sibs well. Placenta small with an area of calcification. Clinical features: elongated skull with bilateral flattening, malformed normally situated ears. High-arched palate, extreme micrognathia. Mild flex- ion deformity of fingers, bilateral short thumbs. Pro $\frac{\mathbb{D}}{2}$ minent heels, short very wide halluces, partial syndactyly of toes 4,5 . Shoulder abduction hypermobile. Shorg sternum, narrow thorax. Congenital heart disease sus pected. Neurologically, extreme general hypotonia apathetic. Movements symmetrical but poor. Pris? mary walking present, Moro satisfactory. Grip reflexo absent even when favoured by sucking. Did not cryo during neurological examination-very unusual. Opis $=\overline{\bar{n}}$ thotonic posture. Tube-fed, slowly gaining weight. $\mathrm{D}$ Hydrocephalus developing. Alive at $2 \frac{1}{2}$ months. Dermatoglyphs: 4 simple arches, 3 ulnar loops, 3 radiaion loops; normally situated $t$ triradius; simian crease, right $-\overrightarrow{0}$ hand. Chromatin positive. Chromosomes: $47, \mathrm{XX}, 18+$.

\section{SC $120766 / 3465$ 우 (Fig. 2b)}

First child died at 5 days, had multiple congenital anomalies. No other relevant family history or consanguinity. Pregnancy complicated by extreme hy- $\omega$ dramnios. Clinical features: elongated (a-p) skull, N wide-set eyes, low-set malformed rotated ears, microg- $V$ nathia. Dimple in chin. Neck short, webbed. Capil-을 lary haemangioma on upper lip. Flexion deformity of $\rightarrow$ fingers. Distal phalanges very short, spatulate. Shield os chest, short sternum. Toe-nails virtually absent. Sucked poorly. Cry extremly high pitched, wailing like $\underset{\mathbb{D}}{\mathbb{D}}$ 'cri-du-chat' cry. Neurologically, extreme general 3 hypotonia, appeared to be blind. Hypermobile shoul- $\mathbb{\Phi}$ ders, could meet in ventral midline (clavicles present). $\vec{\oplus}$ Mild hydrocephalus. Failed to thrive, died at 3 montho 8 Necropsy: normal heart, hydronephrosis, hydroureteg other systems normal (M. B. King). Dermatoglyphs: simple arches, 4 loops; normally situated $t$ triradius; palmar creases bilaterally. Chromosomes: 46,XX. Parents also had normal chromosomes. No clinical details available about older sib, but at necropsy (death at 5 days), infant weighed $1728 \mathrm{~g}$., head circumference $34 \mathrm{~cm}$. Legs oedematous. Right side of heart enlarged. Patent foramen ovale, high ventricular septal defect. Right ventricle emptied by truncus arteriosus guarded by 4 semilunar valves. Only one coronary artery. Left kidney, ureter absent. Brain-considerable dilatation of both lateral ventricles (M. B. King).

\section{Patau's Syndrome}

\section{SE $190765 / 2778$ ㅇ}

Two sibs well. Mongol in father's family. Clinical features: microcephaly, sloping temples, virtually absent nose, severe bilateral cleft lip and palate. Hypertelorism, oblique palpebral fissures. Normal ears, hands, feet. Limited hip abduction. Exomphalos. Hypotonia, apnoeic attacks. Congenital heart disease. Died at 26 days. Necropsy (P. Trott): skull bones asymmetrical, abnormally thin in circular patches. Globular heart, hypertrophic, dilated right ventricle. Atrial septal defect, ventricular septal defect, persistent ductus arteriosus. Right tube and ovary absent. Brain (R. G. Spector)-absent olfactory nerves. Ependyma thick with subependymal sclerosis. Foetal $\mathrm{Hb} 70 \%$. Dermatoglyphs: normal finger-prints; no ridges on palms; no

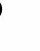


fibular $S$ hallucal arch on sole; bilateral simian creases. Chromosomes: 47,XX,D+.

\section{PF $160866 / 3461$ o}

Clinical features: microcephaly, wide-set eyes, epicanthic folds, low-set malformed ears, cleft lip and palate, micrognathia. Short neck with excess nape skin. Capillary haemangiomas on forehead, eyelids. Flexion deformity of fingers, long hyperconvex finger-nails. Mild equino-varus feet. Abduction of hips, shoulders limited. Six digits on hands. Exomphalos, undescended testes, hypospadias. Generalized hypertonia. Heart sounds normal. Large scalp defect about $5 \mathrm{~cm}$. square. Fed with difficulty, failed to thrive, died at 9 days. No necropsy. Dermatoglyphs: 5 simple arches, 4 loops, 3 digits with ridge dysplasia; $t$ triradius extremely distally situated bilaterally; simian crease on left hand; no fibular $S$-shaped hallucal arch on sole. Chromatin negative. Chromosomes: $47, \mathrm{XY}, \mathrm{D}+$.

\section{LG 231165/2967 ○ (Fig. 3c)}

Umbilical cord only $18 \mathrm{~cm}$. long. Clinical features: microcephaly (head circumference $31 \mathrm{~cm}$., crown-heel $44 \mathrm{~cm}$.), skull elongated antero-posteriorly, with prominent occiput and prominent supraorbital ridge. Eyes wide-set, epicanthic folds (West Indian baby). Bilateral cataracts, in right eye very large. Ears low-set, malformed. Severe bilateral cleft lip and palate, extreme micrognathia. Neck short but no excess skin folds. Capillary haemangiomata on eyelids. Long hyperconvex finger-nails, particularly right hand, retroflexible thumbs, also more marked on right. Bilateral double halluces (Fig. 5c), hypoplastic toe-nails. Thorax shieldshaped, with very wide-spaced nipples. Neurologically, 'twitches', general hypotonia, opisthotonic posture. Congenital heart disease suspected. Died at 6 days. Necropsy: valvular foramen ovale but no other cardiac abnormality. Brain-underdeveloped olfactory bulbs but an intact cribriform plate. Dermatoglyphs: ridge dysplasia on fingertips, palms, soles. Oral smears chromatin positive. Blood smears chromatin positive but negative for granulocyte nuclear projections usual in Patau's syndrome. Chromosomes: 46 chromosomes, normal female with a marker D chromosome: 46,XX,Dp +. Parents not available for study.

\section{MJ 100665/2739 우}

Unmarried, mentally retarded West Indian mother. Of 6 sibs, 5 alive, including 2 sets of twins, 1 died of sickle-cell anaemia. Some, if not all sibs, said to be retarded but not congenitally malformed. Clinical features: microcephaly, scalp defect, wide-set eyes, epicanthic folds (negroid), left microphthalmos, low-set malformed ears, bilateral cleft lip and palate. Both hands, both feet had 6 digits. Flexion deformity of fingers, long hyperconvex nails. Equino-varus feet, prominent heels, short dorsiflexed halluces. Umbilical hernia. Neurologically - generalized hypotonia, no auditory attention, apnoeic spells, seizures. Fed poorly, failed to thrive, died at 14 days. Necropsy (R. G.
Spector): heart dextroposed, anteriorly rotated. Foramen ovale, ductus arteriosus patent. Aortic valve biscuspid, single orifice for coronary vessels. Right lung bi-lobed, upper lobe incompletely divided. Left lung had one lobe. Very small thymus. Accessory spleen. Gall-bladder intrahepatic. Uterus bicornuate. Brain-absent olfactory nerves. Other systems normal. Foetal $\mathrm{Hb} 59 \%$. $\mathrm{Hb} \mathrm{S}$ present (negro). Dermatoglyphs: distal $t$ triradius; soles had fibular Sshaped hallucal arch patterns; transverse distal palmar creases bilaterally. Oral smears chromatin positive. Blood smears chromatin positive, with excess of granulocyte nuclear projections usual in Patau's syndrome. Chromosomes: $47, \mathrm{XX}, \mathrm{D}+$.

\section{SM 280466/3232 के}

Family history of hydrocephalus and cleft palate in 2 of father's relatives. Clinical features: scalp defect, sloping temples, bilateral microphthalmos, hyperterorism, low-set malformed ears, bilateral cleft lip and palate. Capillary haemangioma on forehead. Short neck. Ulnar polydactyly on right hand, bilateral flexion deformity of fingers, finger-nails long, hyperconvex. Mild equino-varus feet, prominent heels. Inguinal hernia, bilateral undescended testes. Failed to thrive, died at 6 days. Necropsy: huge pentagonal defect of soft palate. Heart normal, foramen ovale, ductus arteriosus patent, aorta, pulmonary arteries normal. Kidneys enlarged, especially on right with a right hydroureter and two separate ureters with separate connexions with the renal pelvis and bladder on left. Gallbladder large, lobulated. Right testis absent. Brain: absent olfactory nerves. Dermatoglyphs: total dysplasia of dermal ridges on finger-tips, palms, soles; no simian creases but abnormal palmar creases. Chromatin negative. Chromosomes: 46,XY,D - t $(\mathrm{DqDq})+$. (Parents: 46,XX, 46,XY.)

\section{HP 080966/3509 o}

Placenta abnormally small (340 g.). Clinical features: microcephaly (head circumference, $32 \mathrm{~cm}$.), hypertelorism, epicanthic folds, bilateral microphthalmos, low-set malformed ears, bilateral cleft lip and palate. Short neck with extra nape skin. Capillary haemangiomata on forehead, eyelids. Six digits on hands, flexion deformity of fingers, long hyperconvex finger-nails. Feet normal except for hypoplastic toe-nails. Testes undescended, congenital heart disease suspected. Fed with difficulty, hypotonia, seizures, severe breath-holding spells requiring artificial respiration. Died at 3 days. Necropsy: heart not examined. Seven accessory spleens. Double ureters. Intestine malrotated. Brain -absent olfactory bulbs, reduction in size of parietal and frontal lobes. Foetal $\mathrm{Hb} 70 \%$. Dermatoglyphs: 4 loops, 8 areas of dysplasia on 12 digits; dermal ridge dysplasia of palms. Chromatin negative. Chromosomes: $47, \mathrm{XY}, \mathrm{D}+$.

\section{CW $110665 / 2740$ o}

Three sibs well. No family history of congenital malformations. Pregnancy normal, spontaneous vertex 


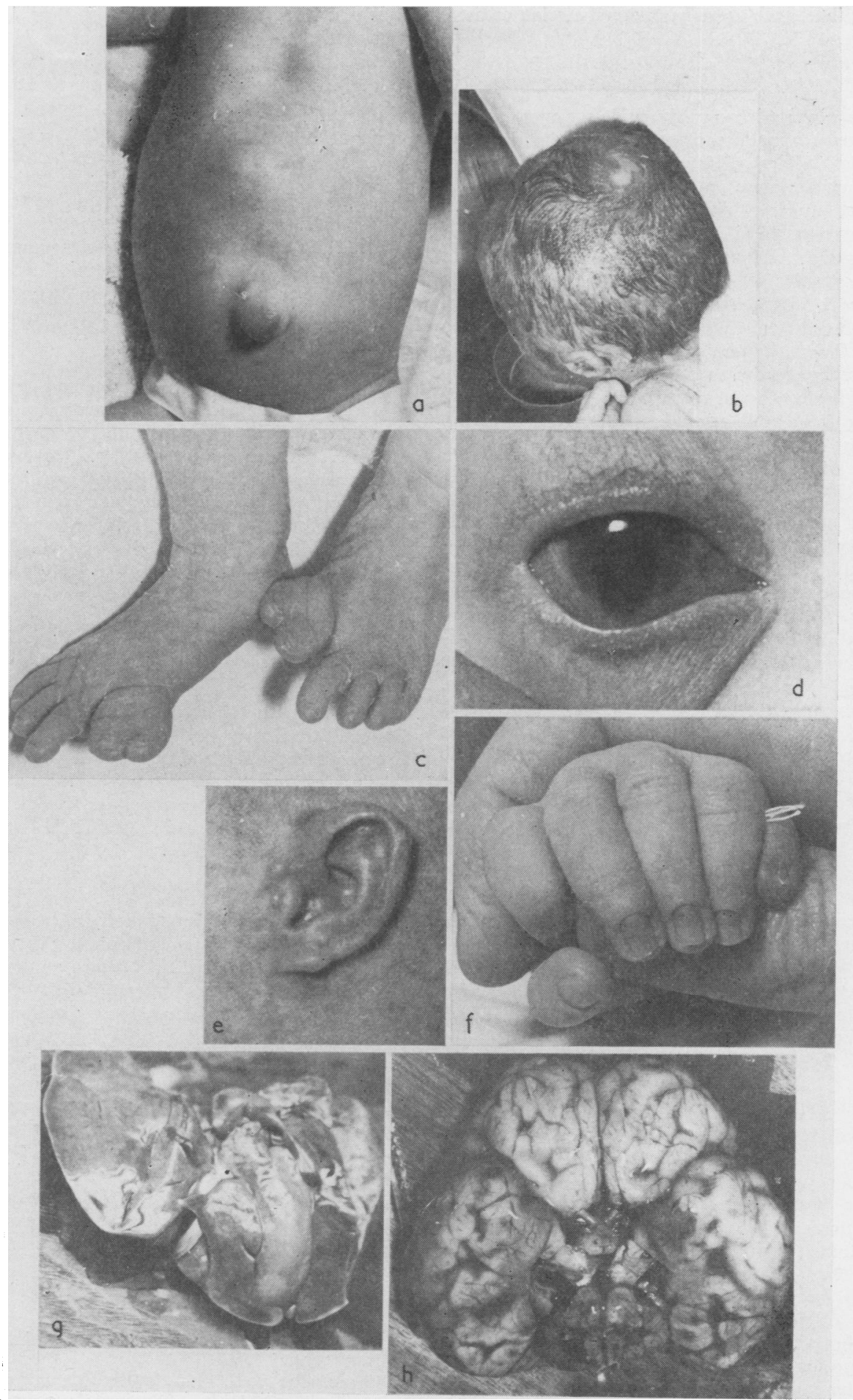

Fig. 5. Patau's syndrome. (a) TP 210667/4092, abdomen showing umbilical hernia and additional area of weak body wall musculature $(47, X X, D+)$; (b) MR 020464/1492, back of head showing scalp defect (46,XX,D - t(DqDq) +); (c) LG 231165/2967, feet showing syndactyly-polydactyly (46,XX,Dp +); (d) LB 290367/3855, right eye showing iris coloboma (46,XY,Bp-); (e) MF 080167/3761, left ear showing accessory auricles $(47, X X, D+)$; (f) LA $080467 / 3921$, left hand showing hyperconvex finger-nails and polydactyly $(47, X X, D+)$ (g) VN 080967/4158, liver showing intrahepatic gall-bladder (46,XX,D -,t(DqDq) +); (h) MR 020464/1492, brain showing absent olfactory nerves $(46, X X, D-, t(D q D q)+)$ and small asymmetric optic nerves. 
delivery. Clinical features: microcephaly with sloping temples, scalp defect, wide-set eyes, epicanthic folds. Eyes normal except for high myopia. Severe cleft lip and palate, micrognathia, short neck. Hands normal. Left foot deformed, short dorsiflexed halluces. Tube fed, gained weight well. At 5 weeks he went home. Breathholding spells followed by cyanosis and rigidity at least once a day. Neurologically (N. O'Doherty)-absent auditory attention, absent auditory response, confirming parents' observation that he could not hear. Looked at and followed bright objects. Rooting present bilaterally. Moro grossly limited but symmetrical. Stepping present only after neck extension, better on right. Died at 135 days. No necropsy. Foetal $\mathrm{Hb}$ $72 \%$. Dermatoglyphs: 2 simple arches, 8 narrow loops. Oral smears chromatin negative, blood smears also chromatin negative, showed excess of granulocyte nuclear projections usual in Patau's syndrome. Chromosomes: 47,XY,D +.

\section{MR 020464/1492 \& (Fig. 3f)}

Younger sib well. Pregnancy complicated by severe toxaemia, labour induced at 34 weeks. Condition at birth poor. Clinical features: microcephaly, sloping temples, scalp defect (Fig. 5b), flat triangular nose, wideset eyes with iris colobomata, low-set malformed ears, micrognathia. Capillary haemangiomata on eyelids, forehead. Flexion contractures of wrists, fingers. Short, very broad dorsiflexed halluces. Sucked poorly, had seizures, severe breath-holding spells, died at 6 hours. Necropsy (A. Claireaux): heart small, malrotated, coarctation of aorta. Kidneys very large, with microscopical appearance of polycystic disease. Brainabsent olfactory nerves, small asymmetrical optic nerves (Fig. 5h). Blood groups unremarkable except for anomalous inheritance of $\mathrm{Xg}$. Proposita was $\mathrm{Xg}(\mathrm{a}-)$, both parents being $\mathrm{Xg}(\mathrm{a}+)$. Other blood groups normally inherited. Foetal $\mathrm{Hb} 67 \%$. No dermatoglyphs examined, but bilateral simian creases. Oral smears chromatin positive. Blood smears chromatin positive, did not show excess of granulocyte nuclear projections usual in Patau's syndrome. Chromosomes: $46, \mathrm{XX}, \mathrm{D}-\mathrm{t}(\mathrm{DqDq})+$. Both parents had normal chromosomes.

\section{NW 091063/1350 ๙}

Clinical features: microcephaly (head circumference $30 \mathrm{~cm}$.), skull, scalp defects, small close-set eyes, large flat triangular nose, micrognathia. Six digits on hands. Genitalia abnormal, very small penis, hypoplastic scrotum. Heart sounds normal. Hypotonia, cyanotic attacks, died on first day of life. Necropsy: heart normal. Hiatus hernia. Meckel's diverticulum. Right kidney, suprarenal larger than left organs. Right testis absent. Brain-normal. Dermatoglyphs: 3 whorls, 2 ulnar loops, remainder not visible; $t$ triradii in $t^{\prime \prime}$ position. Chromosomes: 47,XY,D +. (Case previously published, Taylor and Polani, 1964, Case 8.)

\section{SC $300763 / 1322$ कै}

Younger and older sibs, both boys, alive, well. No relevant family history. Spontaneous normal vertex delivery. Condition at birth poor. Clinical features: severe bilateral cleft lip and palate, micrognathia, microcephaly, 2 scalp defects. Flexion deformity of fingers, contractures of thumbs. Epigenetic hernia, small exomphalos. Testes undescended, penis short. Muscle tone normal, responded to pinprick, probably not to sound. Harsh systolic murmur. Condition gradually deteriorated, cyanotic, dyspnoeic attacks, died at 1 month. At death weighed $907 \mathrm{~g}$. less than at birth. Necropsy (R. G. Spector): lungs-incomplete cleavage between lobes; heart-hypertrophy of both ventricles, dilatation of right atrium. Pulmonary artery arose anteriorly, contained 2 malformed cusps. Large ventricular septal defect, patent foramen ovale, 2 small defects in septum secundum. Ductus closed. Tip of tongue bifid. Fibrous band connected appendix to umbilicus. Testes on pelvic brim. Brain-absent olfactory tracts, short corpus callosum with no splenial thickening. Anterior commissure absent. Numerous groups of heterotopic nerve cells in cerebellar white matter, vermis small. Dermatoglyphs: 5 ulnar loops, 1 radial loop, a tented arch, 3 whorls; $t$ triradius in $t^{\prime \prime}$ position; fibular S-shaped hallucal arch on both feet. Chromatin negative. Chromosomes: 47,XY,D+. (This case previously published, Taylor and Polani, 1964, Case 7.)

\section{JM 100862/1017}

Clinical features: small wide-set eyes, complete bilateral cleft lip and palate, simple low-set ears, micrognathia. Microcephaly. Flexion deformity of fingers, long hyperconvex finger-nails. Testes undescended, penis very small, buried in scrutum. One umbilical artery. Cardiac murmur, died at 19 days. Necropsy: ventricular septal defect, patent ductus arteriosus. Absent rib on left. Ureters, iliac veins abnormal. Brain (R. M. Norman)-absent olfactory nerves, very small optic nerves, particularly on right, short corpus callosum. Numerous heterotopic collections of nerve cells in cerebellar white matter, vermis small. No dermatoglyphic studies. Chromosomes: 47,XY,D +.

\section{MR 030664/1541 ðَ}

Two previous pregnancies resulting in previable foetuses both born at 24-26 weeks. Present pregnancy complicated by hydramnios. Clinical features: downward slanting eyes, deformed nose, drooping forehead, scalp defect. Eyes not visible, anophthalmia suspected. Genitalia probably male, underdeveloped, testes undescended. ? Died at 1 day. Necropsy: heart, persistent truncus arteriosus, ventricular septal defect. Kidneys macroscopically normal. Gut partially malrotated with caecum lying in midline. Small cyst of umbilical cord with sinus containing meconium connecting umbilicus and small intestine. Two umbilical arteries. Brain (R. M. Norman)-grossty abnormal. Typical fullblown arrhinencephalic, rudimentary cerebral hemispheres, absent olfactory tracts, single cerebral ventricle. Cerebellum contained large groups of heterotopic nerve cells, vermis hypoplastic. Optic chiasma absent, orbits 
empty. Dermatoglyphs: not studied. Chromosomes: $47, \mathrm{XY}, \mathrm{D}+$.

\section{VP $241066 / 3598$ 우}

Birthweight 3655 g. (placenta 708 g.), unusually high. Clinical features: wide-set eyes, epicanthic folds, bilateral microphthalmia, iris coloboma on right, coloboma and/or cataract on left. Ears low set, malformed, micrognathia. Neck short with excess nape skin. Severe flexion deformity of fingers, long hyperconvex finger-nails; 6 digits right hand, 7 left hand, 6 on both feet. Prominent heels, hypoplastic toe-nails. Hip abduction limited. Hypertonia, suspected congenital heart disease. No seizures, no apnoeic spells, auditory attention positive. Fed satisfactorily, gained weight. General impression-looked like Patau's syndrome, but too robust. Began to vomit after feeds, had some cyanotic spells, died of aspiration pneumonia at 26 days. Necropsy (P. M. Forster): heart enlarged, globular due to dilation of right atrium, right ventricle. Small high ventricular septal defect. Persistence of left superior vena cava. Pulmonary valve bicuspid. Uterus bicornuate. Brain macroscopically normal. Dermatoglyphs: 4 digits on left hand, simple arches; no pattern on fifth, sixth digits; patterns on right fingertips and palm could not be inspected due to severe flexion deformity; distal $t$ triradius on left, bilateral single palmar creases. Oral smears chromatin positive. Blood smears also chromatin positive, showed excess of granulocyte nuclear projections usual in Patau's syndrome. Chromsomes: 3 cell lines, $46, \mathrm{XX} ; 47, \mathrm{XX}, \mathrm{D}+; 48, \mathrm{XX}, \mathrm{D}+, \mathrm{D}+$. Tetrasomic cell line minor, not in skin. Other 2 lines present in both tissues (blood and skin): 46,XX/47,XX, $\mathrm{D}+/ 48, \mathrm{XX}, \mathrm{D}+, \mathrm{D}+$.

\section{MF $101166 / 3624$ वे}

Two sibs well. Clinical features: bilateral microphthalmos, low-set malformed ears, very severe cleft lip and palate, micrognathia. Neck short with excess nape skin. Hands and feet had 6 digits. Long hyperconvex finger-nails. Calcaneo-valgus feet, short dorsiflexed big toes. Chest shield-shaped. Testes undescended. Congenital heart disease, died at 8 hours. Necropsy: interventricular septal defect about $5 \mathrm{~mm}$. diameter just below aortic and tricuspid valves. Foramen ovale patent, abnormally situated, led into very rudimentary left atrium. Ductus arteriosus patent. Renal and other systems normal. Brain-absent olfactory bulbs, absent optic chiasma. Dermatoglyphs, not studied. Oral smears chromatin negative, blood smears chromatin negative, no granulocyte nuclear projections normally found in Patau's syndrome. Chromosomes: 47, XY,D+.

\section{JC 131066/3781 우}

Older sister well. One macerated stillbirth. Clinical features: bilateral microphthalmos, bilateral cleft lip, cleft palate. Extra skin at nape, pilonidal sinus. Hypotonic, jittery, apnoeic spells. Exomphalos. Left hand had 6 digits. Fed poorly, jaundiced, bled from mouth, died at 3 days. Necropsy: heart, enlargement of right atrium, large atrial septal defect due to failure of development of septum secundum. Ductus patent. Kidneys enlarged, congested, cyst in upper pole left kidney. Tail of pancreas bifid. Brain-absent olfacfactory nerves. No dermatoglyphs. Chromosomes: $47, \mathrm{XX}, \mathrm{D}+$. (Studied by W. M. Davidson.)

\section{MF 080167/3761 ㅇ (Fig. 3d)}

Sib has coeliac disease, other 2 sibs well. No family history of congenital malformations, 2 sets of twins in father's family. Clinical features: antero-posterior elongation of skull, wide-set eyes, epicanthic folds, bilateral iris colobomata, low-set malformed ears with accessory auricles (Fig. 5e), micrognathia. High arched palate with calcified soft palate. Small tongue, uvula absent. Capillary haemangiomata on eyelids, back of neck, abdomen near umbilicus. Both hands had 6 digits, flexion contracture of fingers. Finger-nails long, hyperconvex, toe-nails hypoplastic. Mild equino-varus feet. Narrow thorax, small umbilical hernia. Sucked poorly, bouts of jaundice, apnoeic attacks. Auditory attention negative. Muscle tone normal. Congenital heart disease suspected. Failed to thrive, died at 67 days. Necropsy: heart enlarged, no septal defects or coarctation of aorta. Ductus arteriosus patent. Kidneys bilaterally enlarged, lobulated. Uterus biseptate, absence of left cornu, tube, ovary. Accessory spleen. Brainabsent olfactory nerves. Dermatoglyphs: 9 simple arches, 1 narrow loop; sixth digits rudimentary; position of $t$ triradius not recorded; fibular S-shaped hallucal arch on both soles; 2 palmar creases bilaterally. Chromatin positive. Chromosomes: $47, \mathrm{XX}, \mathrm{D}+$.

\section{KA 290367/3856 옹}

Sib had pyloric stenosis but well. Clinical features: microcephaly, wide-set very small eyes, low-set malformed ears, cleft palate, micrognathia. Neck short, excessive nape skin. Six digits on all hands and feet. Thumbs flexed abnormally, hip abduction tight. Thorax unusually narrow. Heart sounds normal. General hypertonia. Jaundiced, fed with difficulty, breath-holding spells, died at 4 days. Necropsy: abnormal heart, rudimentary atria, polycystic renal cortex, biseptate uterus, pyloric stenosis (also present in sib). Accessory liver lobules. Brain-absent olfactory tracts and bulbs, small optic chiasma. Both eyes, microphthalmos, aniridia, cataract, retrolental retinal dysplasia, coloboma of retina, and choroid. Left eye had intraocular cartilage (G. Keith). Dermatoglyphs: 9 loops, 1 whorl, sixth digits dysplastic. Normally situated $t$ triradius, 2 palmar creases bilaterally; complete ridge dysplasia of soles. Oral smears, chromatin positive; blood smears, characteristic granulocyte nuclear projections. Chromosomes: 47,XX,D+.

\section{LA 080467/3921 우 (Fig. 3a)}

Younger brother well. No relevant family history. Delivery normal. Condition at birth fair. Pneumonia soon after birth, recovered. Clinical features: bilateral cleft lip and palate, poorly developed nose, microcephaly, microphthalmia, wide-set eyes with mongoloid 
slant, epicanthic folds, micrognathia, short neck. Scalp defect. Normal ears. Capillary haemangiomata on eyelids, forehead. Six digits on left hand (Fig. 5f). Neurologically-moved symmetrically, generalized hypotonia. Auditory attention negative. Heart sounds normal. Cyanotic spells followed feeds. No seizures or breathholding attacks. Feeding difficulty due to hare-lip and cleft palate, but tried to suck, gained some weight. Died at $5 \frac{1}{2}$ months. Necropsy: no abnormalities except brain which had enlargement of both lateral cerebral ventricles. Abnormal persistence of foetal $\mathrm{Hb}, 50 \%$ at 2 months, $31 \%$ at 3 months. Dermatoglyphs: 7 simple arches, 4 loops on 11 fingertips; $t$ triradius in $t^{\prime \prime}$ position, 2 palmar creases bilaterally. Oral smears chromatin positive. Blood smears chromatin positive, showed typical granulocyte nuclear projections in large numbers. Chromosomes: $47, \mathrm{XX}, \mathrm{D}+$.

\section{PS $120767 / 4072$ o (Fig. 3g)}

First child delivered at 7 months after ante-partum haemorrhage, weighed $793 \mathrm{~g}$., died at 8 hours. Other sib well. Brother of father has a mongol. Pregnancy complicated by pyelitis at 4 months. Caesarian section at 38 weeks. Condition at birth poor (Apgar 2). Clinical features: microcephaly (head circumference $34 \mathrm{~cm}$.), scalp defect, wide-set small eyes, cleft palate, micrognathia. Low-set ears with accessory auricles. Neck short with excess nape skin. Capillary haemangiomata on forehead, eyelids, thorax. Hands, feet had 6 digits. Flexion deformity of fingers, long hyperconvex finger-nails. Feet normal. Short sternum, shieldshaped thorax. Undescended testes, scrotum very small. Congenital heart disease suspected. Hypotonic, breath-holding attacks, seizures. Auditory attention negative. Fed with difficulty, failed to thrive, died at 61 days. Necropsy: heart dextroposed, complete transposition of great vessels. Atrial, ventricular septal defects, persistent ductus arteriosus. Pulmonary trunk small, failed to communicate with any chambers. Pulmonary valve rudimentary. Kidneys - marked foetal lobulation, numerous cysts of renal parenchyma; two right renal veins. Brain-macroscopically normal except absence of olfactory nerves. Dermatoglyphs: 7 simple arches, 3 whorls; sixth digits-no patterns; $t$ triradii in $t^{\prime \prime}$ position, bilateral single palmar creases. Blood smear chromatin negative, showed excess of granulocyte nuclear projections typical of Patau's syndrome. Chromosomes: 47,XY,D+.

\section{TP 210667/4092 $q \quad$ (Fig. 3e)}

Pregnancy normal. Clinical features: hypertelorism, epicanthic folds, bilateral microphthalmos, downward slanting palpebral fissures, low-set normal ears, micrognathia. Not microcephalic. Capillary haemangioma on left thumb. Both hands, feet, 6 digits. Flexion deformity of fingers, hyperconvex finger-nails. Feet normal except hypoplastic toe-nails. Umbilical hernia, an additional patch of thin body wall near umbilicus (Fig. 5a). Generally-hypotonia; auditory attention positive; cyanotic spells after feeds, dextrocardia suspected; appeared retarded, failed to thrive, died at 88 days. Necropsy: heart greatly enlarged, dilatation, hypertrophy of right side. Widely patent foramen ovale, patent ductus arteriosus. Moderate coarctation of aorta. Early bronchopneumonia. Kidneys-thinwalled cysts in cortex. Brain-absent olfactory bulbs. Foetal Hb 54\%. Dermatoglyphs: 5 simple arches, 2 ulnar loops, 2 radial loops on 12 fingers; $t$ triradius in $t^{\prime \prime}$ position, 2 palmar creases bilaterally; fibular S-shaped hallucal arch pattern on both soles. Oral smears chromatin positive. Blood smears showed excess of granulocyte nuclear projections typical of Patau's syndrome, chromatin positive. Chromosomes: 47,XX,D +.

\section{PM 200867/4124 đิ (Fig. 3b)}

Consanguinity, degree unknown. Clinical features: microcephaly (head circumference $32 \mathrm{~cm}$.), very thin right parietal bone; bilateral microphthalmos, hypertelorism, low-set malformed ears, severe bilateral cleft lip and palate, micrognathia. Neck short, excess nape skin. Capillary haemangiomata on forehead, eyelids. Both hands had 6 digits, thumbs proximally implanted, retroflexible. Finger-nails long, hyperconvex. Testes undescended. Congenital heart disease suspected. Neurologically-generalized hypotonia, auditory attention negative; apparently blind, no reaction to electronic flash firing. Fed with difficulty, died at 17 days. Necropsy: heart enlarged, very hypertrophic right ventricle; atrial septal defect, ductus patent. Other systems normal. Brain-absent olfactory bulbs. Foetal Hb 73\%. Dermatoglyphs: 7 ulnar loops, 5 radial loops on 12 fingertips; ridge dysplasia on palms, soles; 2 palmar creases bilaterally. Chromosomes: $47, \mathrm{XY}, \mathrm{D}+$.

\section{JN 240767/4119 ð}

Older sib well. Pregnancy, delivery normal. Clinical features: elongated skull, down-slanting wide-set small eyes. Bilateral iris colobomata. High-arched palate, micrognathia. Face asymmetrical, mouth down on right. Tongue tethered in midline, indented. Neck short, excess nape skin. Flexion deformity of fingers. Feet had 6 digits, short dorsiflexed big toes. Slight umbilical hernia, testes undescended. Feeding difficult, weight gain poor. Palate paralysed. Hypotonic, apnoeic spells. Died at 2 months. No necropsy. Foetal $\mathrm{Hb} 80 \%$ at 1 month (high). Dermatoglyphs: 5 simple arches, 2 radial loops, 1 ulnar loop, 2 whorls; $t$ triradii in $t^{\prime \prime}$ position; single palmar crease on left. Chromosomes: 47,XY,D +

\section{BS $300867 / 4141$ ㅇ}

Two sets of twins in father's family. Pregnancy terminated by caesarian section at 38 weeks due to foetal distress. Clinical features: microcephaly (head circumference $29 \mathrm{~cm}$.), hypertelorism, bilateral microphthalmos, low-set malformed ears, micrognathia. Six digits on right hand, flexion deformity of fingers, retroflexible thumbs. Feet normal. Fed with difficulty, died at 2 days. Necropsy: normal heart, patent ductus arteriosus. Kidneys, ureters normal. Uterus bicornuate. Brain-absent olfactory bulbs, very small optic 
chiasma, deficient corpus callosum. Dermatoglyphs: no ridges on fingertips, palms or soles. Chromosomes: $47, \mathrm{XX}, \mathrm{D}+$.

\section{VN 080967/4158 우}

Clinical features: microcephaly, scalp defect, small wide-set eyes, iris colobomata, severe cleft lip and palate, micrognathia. Malformed ears. Both hands had 6 digits, flexion deformity of fingers. Hyperconvex finger-nails. Calcaneo-valgus feet, convex soles, prominent heels. Normal muscle tone, attacks of jitteriness, apnoea. High-pitched cry, auditory attention negative. Died at 62 days. Necropsy (J. Keall): heart enlarged, otherwise normal. Gall-bladder intrahepatic (Fig. 5g). Kidneys normal. Uterus biseptate. Brain-absent olfactory nerves, deficient corpus callosum. Dermatoglyphs: dysplasia of ridges on fingertips; distally placed $t$ triradii. Chromosomes: $46, \mathrm{XX}, \mathrm{D}-, \mathrm{t}(\mathrm{DqDq})+$. Both parents had normal chromosomes.

\section{LB 290367/3855 ô (Fig. 3i)}

No relevant family history. Pregnancy ended at 30 weeks. Clinical features: cleft palate, unilateral cleft lip, microcephaly, wide-set eyes, bilateral iris colobomata (Fig. 5d), low-set malformed ears, micrognathia. Flexion deformity of fingers, retroflexible thumbs, limited hip abduction. Capillary haemangioma near anus. Testes undescended, glandular hypospadias. Generalized hypertonia, jittery, apnoeic spells. Congenital heart disease suspected. Fed with difficulty, died at 24 hours. Necropsy: (N. M. Davidson): lungs almost completely atelectatic, only demonstrable air in left lower lobe. Heart enlarged with large right atrium, minute left atrium. An 'aorta' arose from left ventricle, including coronary orifices, forming arch, branching only into carotid and subclavian arteries. Vessel arose from right ventricle, giving off pulmonary arteries, continuing as descending aorta on left. Large ventricular septal defect. Left kidney, ureter absent. Both testes pelvic. Dermatoglyphs: total ridge dysplasia on palms, fingertips; 2 palmar creases bilaterally. Chromatin negative. Chromosomes: (Fig. 1c) $46, \mathrm{XY}, \mathrm{Bp}-$. The parents refused to be studied.

\section{DW 301067/4271 o}

Clinical features: microcephaly, wide-set eyes, epican- thic folds, bilateral iris colobomata, low-set malformed ears, deformed flat nose, bilateral cleft lip and palate, micrognathia. Excess nape skin. Capillary haemangiomata on forehead, eyelids, nose. Long hyperconvex finger-nails. Mild equino-varus feet, abnormally long, broad halluces, syndactyly of second, third toes. Undescended testes, rudimentary penis, congenital heart disease. Neurologically; left hemisyndrome. Trunk, legs hypertonic, upper limbs hypotonic. Palmar and plantar grasp deficient on left. Primary walking could not be elicited, probably due to hypertonicity of pelvic girdle and legs. Rooting present bilaterally, asymmetrical tonic neck reflex deficient on left. Moro satisfactory. Died at 3 days. Necropsy: Fallot's tetralogy (large patency of foramen ovale producing virtually a three-chambered heart), hypertrophic ventricles, very narrow pulmonary valve and trunk, interventricular septal defect. Other systems normal. Foetal Hb 58\%. Dermatoglyphs: 6 ulnar loops, 3 radial loops, 1 whorl; normally situated $t$ triradii, but both $d$ triradii missing; 2 palmar creases bilaterally. Chromosomes: 46,XY. Parents have yet to be studied.

\section{GH 051267/4308 $q$ (Fig. 3h)}

A cousin of mother had multiple congenital anomalies. Clinical features: domed skull, hypertelorism, oblique palpebral fissures, small eyes, corneal opacity in right. Hooked nose, small mouth, extreme micrognathia. Flexion deformity of fingers, proximally implanted retroflexible thumbs, tapering fingers, hyperconvex finger-nails. Odd-shaped toes, laterally deviated, oedema of feet. Short neck, much excess nape skin. Generally -hypotonia, cyanotic spells, no fits, sucked poorly. Feeble cry, heart murmur. Neurologically (8 days) rooting, sucking present. Extreme general hypotonia, no head control in dorsal ventral or upright suspension. Palmar grasp fair, symmetrical. Plantar grasp $R>L$. Scissors posture, scissoring of legs in upright suspension. Extensor thrust good, stepping good in spite of hypotonia. General apathy, little spontaneous movement. Alive at 2 weeks. Dermatoglyphs: whorls on 10 digits; extremely distal $t$ triradii bilaterally; bilateral simian creases; no fibular $S$ pattern on soles. Blood smears chromatin positive. Granulocyte projections only in normal numbers. Chromosomes: 46,XX,Dq- (about half a D long arm missing-Fig. 1a). (Parents, 46,XY, $46, \mathrm{XX}$.) 